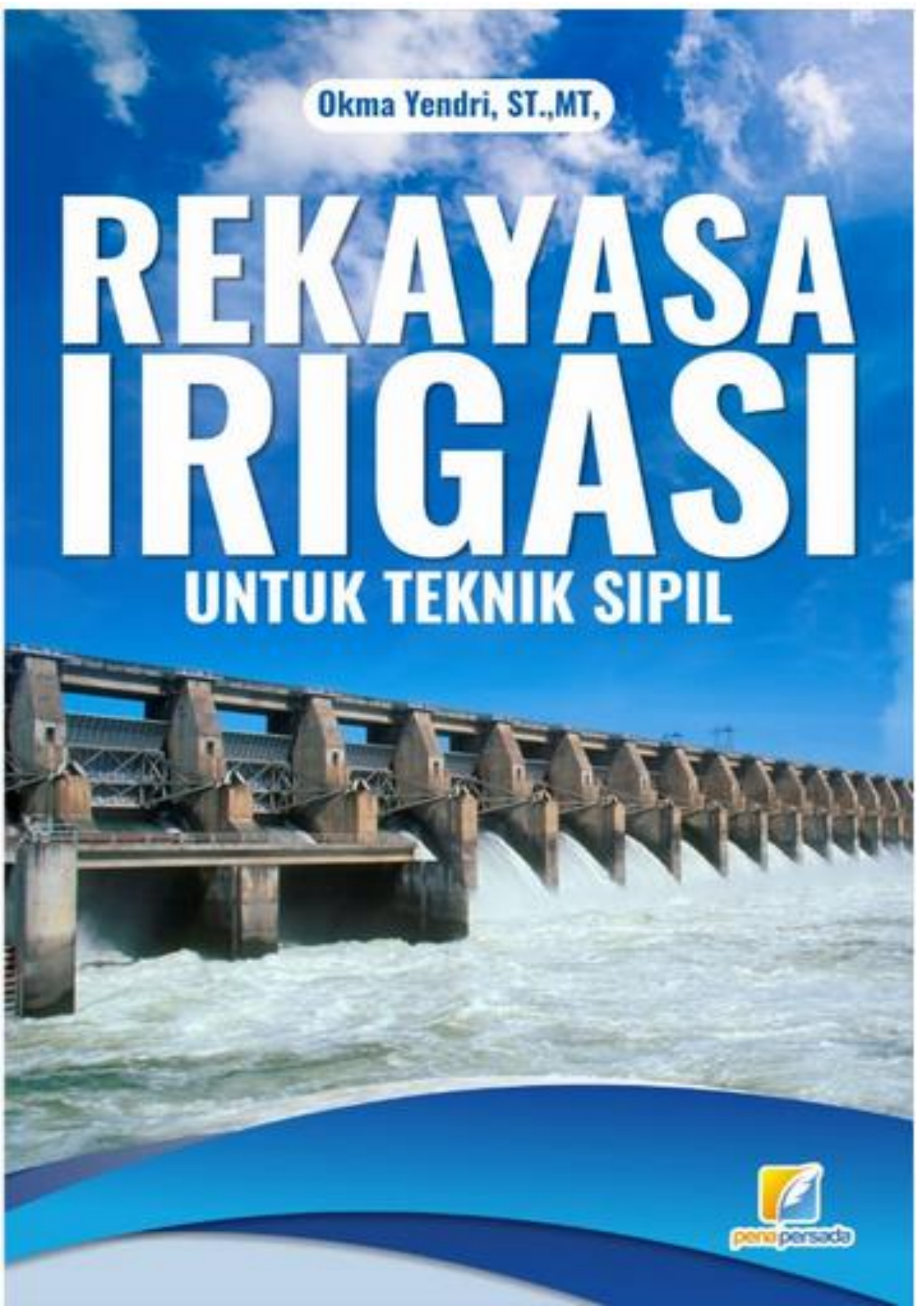




\section{REKAYASA IRIGASI UNTUK TEKNIK SIPIL}

OKMA YENDRI, ST.,MT,

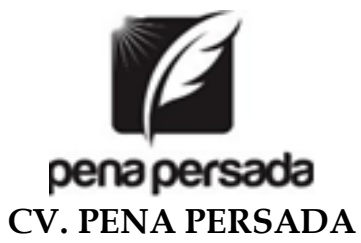


REKAYASA IRIGASI

UNTUK TEKNIK SIPIL

Penulis :

Okma Yendri, ST.,MT,

ISBN : 978-623-315-122-1

Design Cover :

Retnani Nur Briliant

Layout :

Hasnah Aulia

Penerbit CV. Pena Persada

Redaksi :

Jl. Gerilya No. 292 Purwokerto Selatan, Kab. Banyumas Jawa Tengah

Email : penerbit.penapersada@gmail.com

Website : penapersada.com

Phone : (0281) 7771388

Anggota IKAPI

All right reserved

Cetakan pertama : 2021

Hak cipta dilindungi oleh undang-undang.

Dilarang memperbanyak buku ini dalam bentuk dan cara apapun tanpa ijin penerbit 


\section{KATA PENGANTAR}

Puji syukur penulis panjatkan kehadirat Allah S.W.T atas telah selesainya buku ajar ini. Sesuai dengan ketentuan yang ada buku ajar ini merupakan salah satu syarat untuk mengajar pada Program Studi Teknik Sipil Jurusan Teknik, Unversitas Musi Rawa.

Dalam penyelesaian buku ajar ini penulis telah berusahan dengan kemampuan yang ada, namun demikian penulis menyadari masih banyak kekurangan-kekurangan, hal ini disebabkan karena terbatasnya ilmu yang penulis miliki. Atas segala kekurangan tersebut, setiap saran, keritik dan teguran yang sifatnya memperbaiki, penulis menerima dengan alasan yang dapat diterima secara ilmiah, demi kesempurnaan usulan penelitian tesis ini.

Pada kesempatan ini pula penulis mengucapkan bayak terima kasih kepada: Istri KU Nazmawaty, S.Kom, ANAK-ANAK KU Miranda Nabiilaqory, Muthii'ah Novrianty dan Mifta Seftiany.

Semoga dengan amal dan kebaikan Bapak, Ibu Dosen, akan mendapatkan balasan dari Allah SWT.Aamiin.

Lubuklinggau, Januari 2021

Okma Yendri 


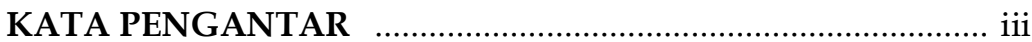

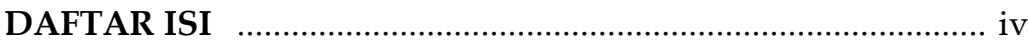

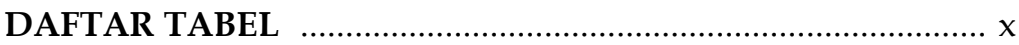

DAFTAR GAMBAR ……………..................................... xiv

BAB I DEFINISI, TUJUAN IRIGASI, SISTEM JARINGAN IRIGASI DAN SUMBER AIR IRIGASI

A. Definisi Irigasi …........................................................... 1

B. Tujuan dan Manfaat Irigasi ………………….................. 3

C. Tingkat-tingkat Jaringan Irigasi ……………….................. 5

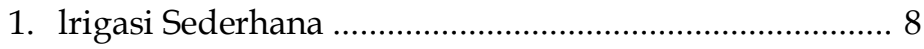

2. Jaringan Irigasi Semiteknis ……................................... 9

3. Jaringan Irigasi Teknis ................................................... 11

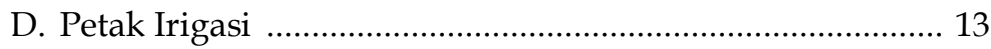

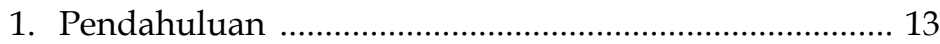

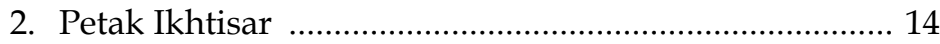

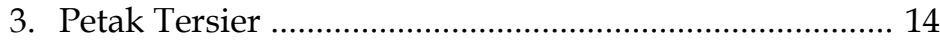

4. Petak Sekunder …............................................................. 15

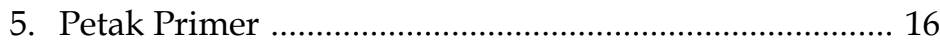

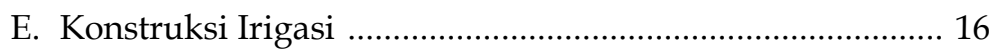

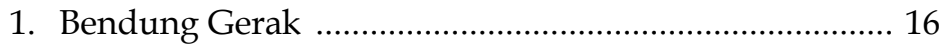

2. Bendung Karet ............................................................. 17

3. Pengambilan Bebas .................................................... 17

4. Pengambilan dari Waduk ............................................. 17

5. Stasiun Pompa .............................................................. 18

6. Saluran Irigasi ................................................................ 18

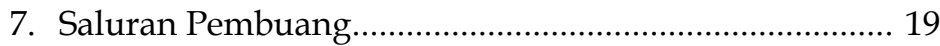

8. Bangunan Bagi dan Sadap ............................................. 20

9. Bangunan-bangunan Pengukur dan Pengatur.............. 21

10. Bangunan Pengatur Muka Air ....................................... 23

11. Bangunan Pembawa......................................................... 23

12. Bangunan Pembawa Dengan Aliran Superkritis........... 23

13. Bangunan Pembawa Dengan Aliran Subkritis

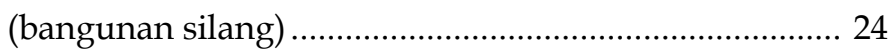

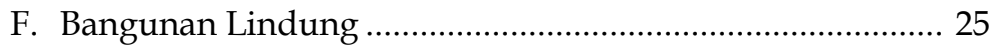

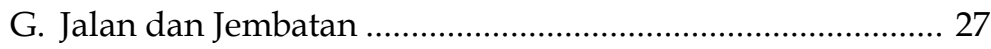




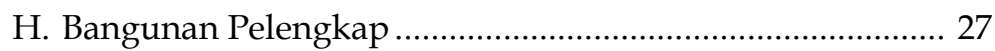

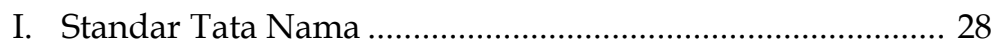

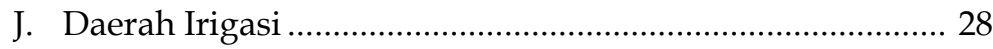

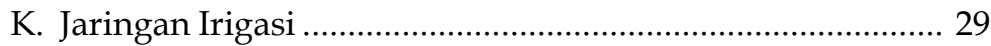

1. Jaringan Irigasi Primer .................................................... 29

2. Jaringan Irigasi Tersier .................................................. 30

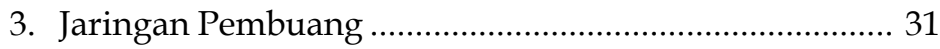

L. Tata Warna Peta ................................................................. 32

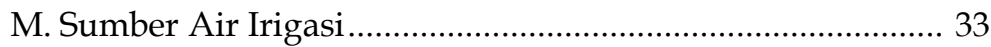

N. Metoda Pendistribusian Air Irigasi .......................................... 34

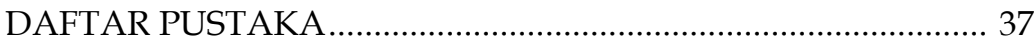

\section{BAB II LAYOUT JARINGAN IRIGASI}

A. Layout Petak Tersier ............................................................ 38

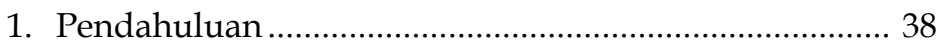

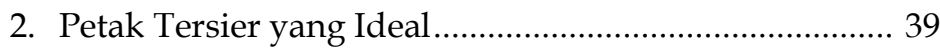

3. Ukuran dan Bentuk Petak Tersier dan Kuarter .............. 42

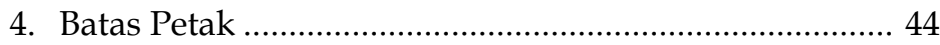

5. Identifikasi Daerah-daerah yang Tak Diairi................... 45

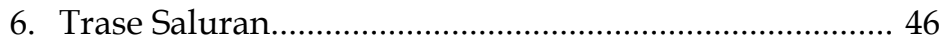

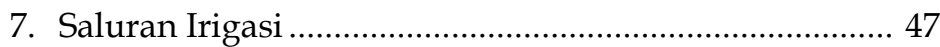

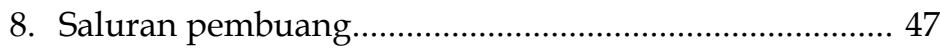

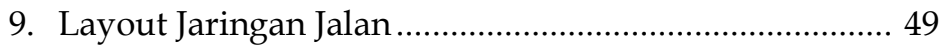

10. Layout di Berbagai Tipe Kontur...................................... 50

a. Layout Pada Kontur Terjal ........................................... 51

b. Layout Pada Kontur Bergelombang .......................... 56

c. Layout Pada Kontur Datar ........................................ 58

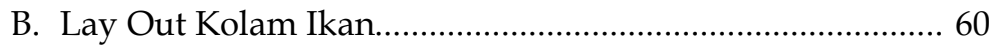

C. Pencekan dan Penyelesaian Layout Pendahuluan................ 64

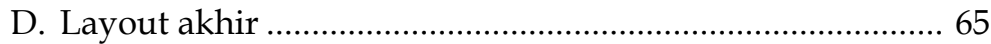

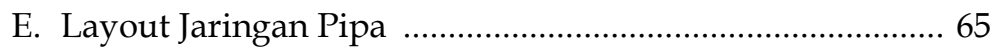

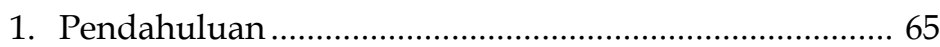

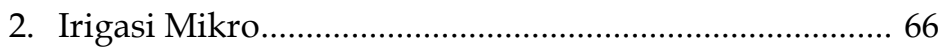

3. Perencanaan Teknis Irigasi Mini ..................................... 67

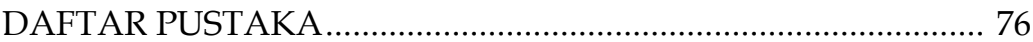

BAB III MACAM-MACAM BANGUNAN SADAP

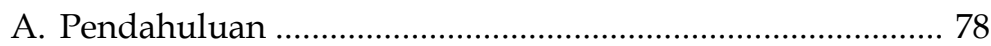




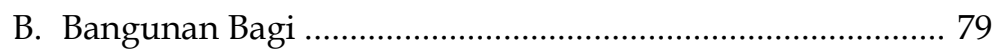

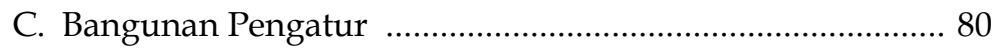

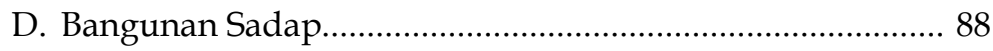

DAFTAR PUSTAKA ................................................................ 95

BAB IV KEBUTUHAN DATA DAN PROSEDUR PERENCANAAN

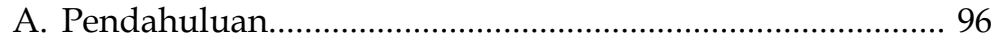

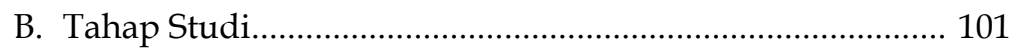

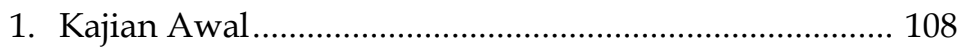

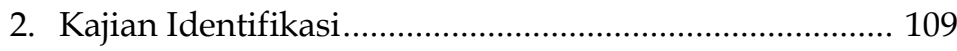

3. Kajian Pengenalan ....................................................... 110

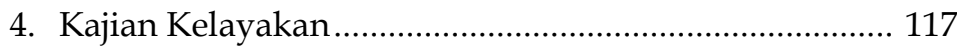

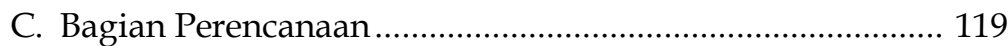

1. Tahap Perencanaan Pendahuluan.................................. 119

2. Perencanaan dan Laporan Akhir .................................... 131

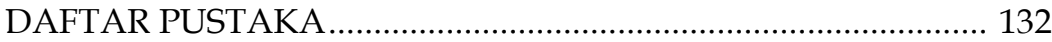

BAB V KEBUTUHAN AIR DAN KAPASITAS RENCANA IRIGASI

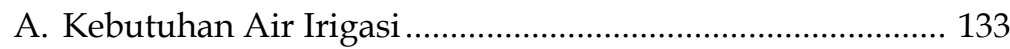

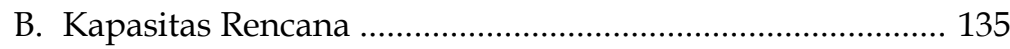

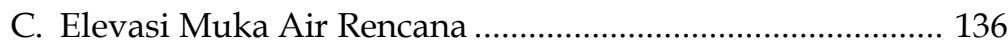

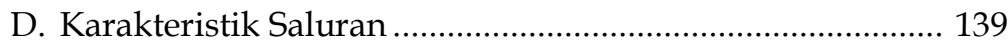

E. Saluran Irigasi/Pembuang Kuarter ...................................... 142

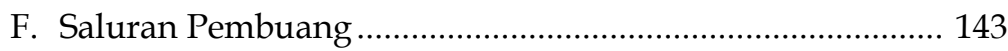

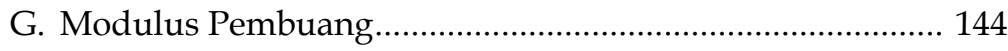

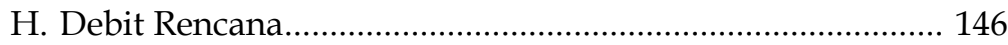

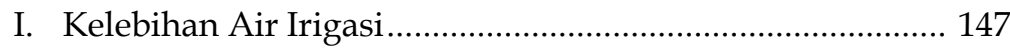

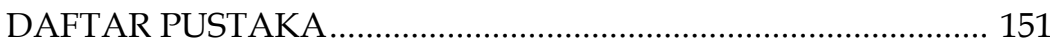

BAB VI ANALISIS, EVALUASI DATA HIDROMETEOROLOGI DAN HITUNGAN KEBUTUHAN AIR UNTUK TANAMAN PADI DI SAWAH

A. Analisis dan Evaluasi Data Hidrometeorologi.................... 152

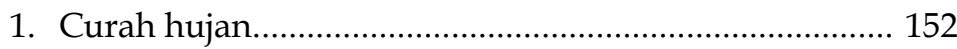

2. Debit Banjir Rencana ..................................................... 156

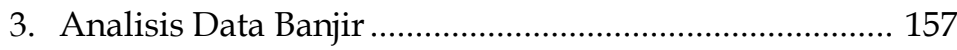

4. Pemilihan Fungsi Distribusi .......................................... 158

5. Pengujian Kecocokan Fungsi Distribusi 
(Goodness Of Fit)

6. Pendekatan Grafis Untuk Menghitung Besarnya Banjir Rencana 162

7. Cara Analitis 163

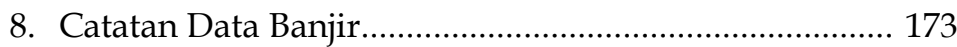

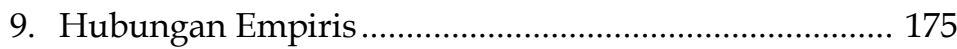

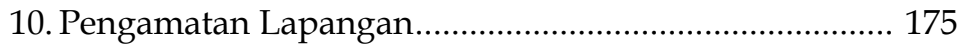

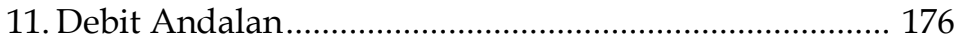

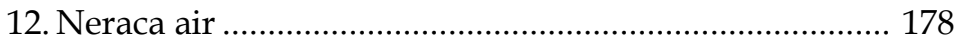

B. Hitungan Kebutuhan Air (Kebutuhan Air Untuk

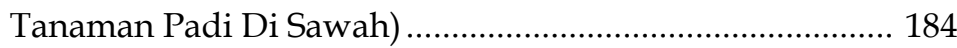

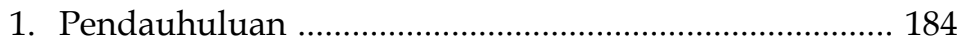

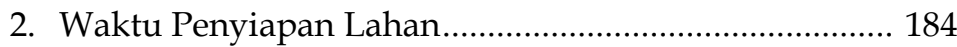

3. Kebutuhan Air Untuk Penyiapan Lahan......................... 185

4. Kebutuhan Air Selama Penyiapan Lahan .................... 187

5. Penggunaan Konsumtif................................................... 189

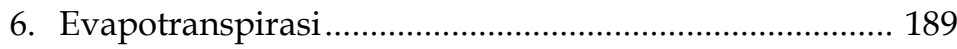

7. Koefisien Tanaman ........................................................ 190

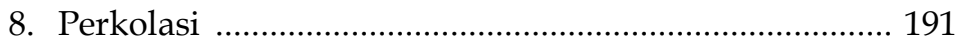

9. Penggantian Lapisan Air .................................................. 192

10. Curah Hujan Efektif ........................................................ 192

11. Perhitungan Kebutuhan Air Di Sawah Untuk Petak Tersier

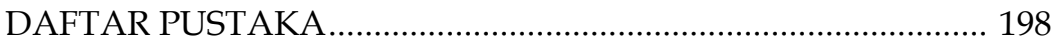

BAB VII DESAIN SALURAN (DIMENSI SALURAN PEMBERI DAN PEMBUANG SAMPAI ROW DAN BANGUNAN PELENGKAP BENDUNG)

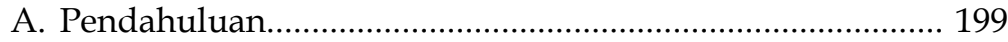

B. Bangunan Pengukur Debit.................................................... 200

C. Alat Ukur Ambang Lebar...................................................... 204

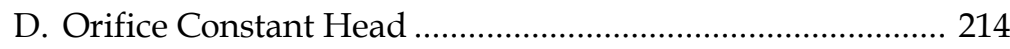

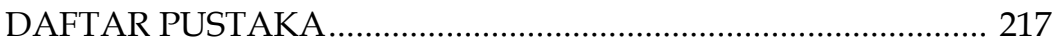

BAB VIII PERENCANAAN BANGUNAN IRIGASI

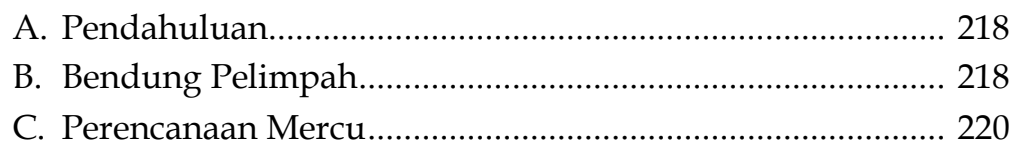




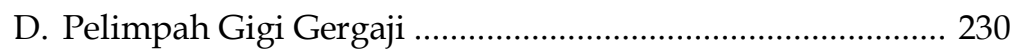

E. Peredam Energi Tipe Bak Tenggelam ................................. 241

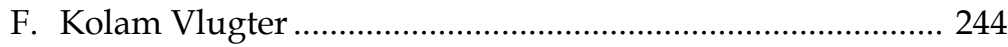

G. Modifikasi Peredam Energi................................................. 245

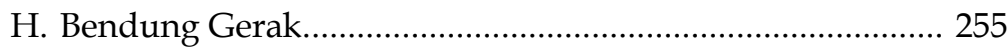

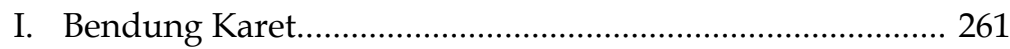

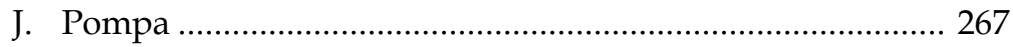

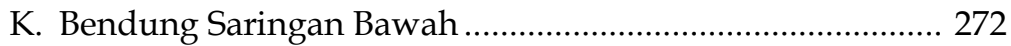

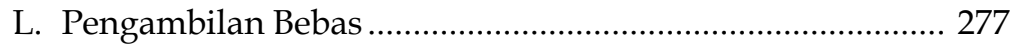

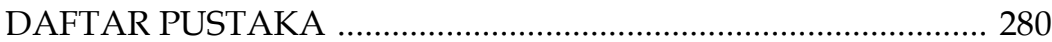

\section{BAB IX ANALISIS STABILITAS BENDUNG}

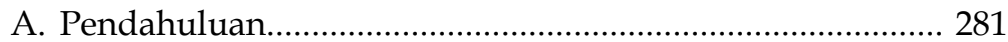

B. Kriteria Perencanaan Stabilitas Bendung............................ 282

C. Gaya-gaya yang bekerja pada Bedung ………...................... 282

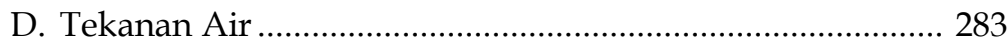

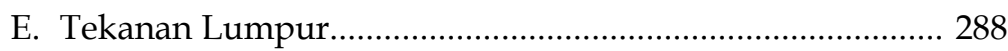

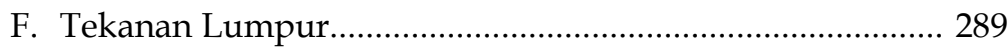

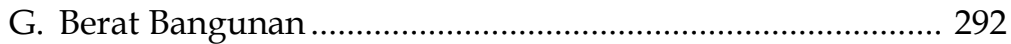

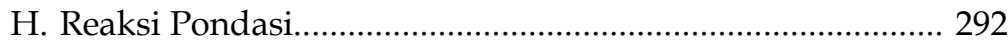

I. Analisa Stabilitas Bendung Karet .......................................... 294

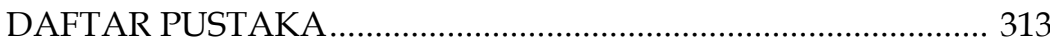

\section{BAB X TEKNIK PENGGAMBARAN}

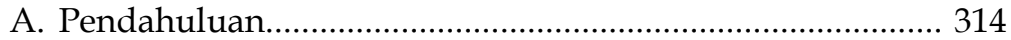

B. Ukuran Kertas Gambar....................................................... 317

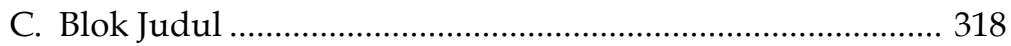

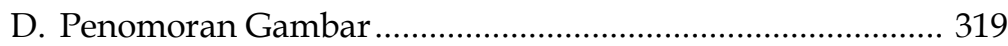

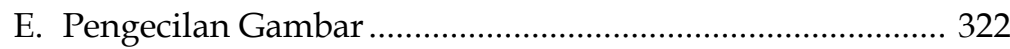

F. Penunjukan Arah Gambar ................................................. 323

G. Skala, Tebal Garis, Tinggi Huruf dan Angka ....................... 324

H. Ukuran dan Indikasi ........................................................ 327

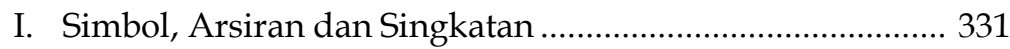

J. Gambar-Gambar Untuk Saluran, Pembuang dan

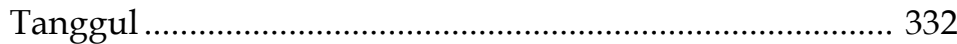

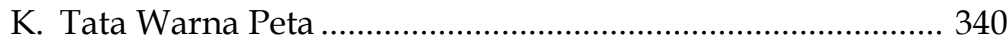

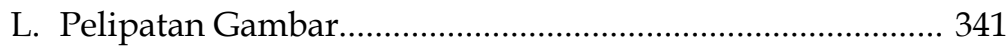

M. Penggambaran Dengan Menggunakan Komputer ............. 342 
N. Mencetak Gambar .......................................................... 343

DAFTAR PUSTAKA................................................................ 376

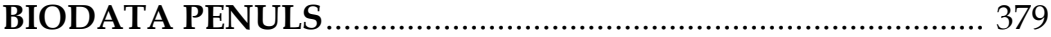




\section{DAFTAR TABEL}

$\begin{array}{lll}\text { Tabel 1.1 Tingkat Jaringan Irigasi } & 6\end{array}$

Tabel 1.2 Alat-alat ukur Irigasi 21

Tabel 2.1 Kriteria Umum Untuk Pengembangan Petak Tersier 44

Tabel 2.2 Berbagai Tipe Kontur 50

Tabel 2.3 Daya Menahan Air Dari Berbagai Tekstur Tanah Setiap Unit Kedalaman

Tabel 2.4 Perkiraan Efisiensi Irigasi (Approximate Application Efficiency) $\quad 70$

Tabel 2.5 Spasi Maksimum Irigasi Sprinkler $\quad 70$

Tabel 3.1 Bangunan Pengatura dan Pegontrol 82

$\begin{array}{lll}\text { Tabel 4.1 Penahapan Proyek } & 97\end{array}$

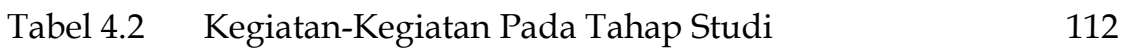

Tabel 4.3 Kegiatan-kegiatan dalam Tahap Perencanaan Jaringan Utama

Tabel 5.1 Kriteria Perencanaan Untuk Saluran Irigasi Tanpa Pasangan

$\begin{array}{lll}\text { Tabel 6.1 Analisis Curah Hujan } & 156\end{array}$

Tabel 6.2 Harga Kritis Kolmogorov Smirnov 162

Tabel 6.3 Hubungan Antara Fungsi Distribusi, Parameter Dan Besarnya Debit Banjir Rencana $\quad 171$

$\begin{array}{lll}\text { Tabel } 6.4 & \text { Standar Gamma (W) } & 172\end{array}$

Tabe; 6.5 Luas Di Bawah Kurva Standar Normal Distribusi $\quad 173$

Tabel 6.6 Kebutuhan Air Irigasi Selama Penyiapan Lahan (IR) 188

Tabel 6.7 Harga - Harga Koefisien ${ }^{1}$ Tanaman Padi 191

Tabel 6.9 Kebutuhan Air Di Sawah Untuk Petak Tersier Jangka Waktu Penyiapan Lahan 1,0 Bulan

Tabel 7.4 Kebutuhan air di sawah untuk petak tersier jangka waktu penyiapan lahan 1,0 bulan

Tabel 7.1 Perbandingan Antara Bangunan -Bangunan Pengukur Debit Yang Umum Dipakai

Tabel 7.3 Contoh hubungan antara jarak vertikal dan kemiringan samping pada papan duga untuk saluran dengan kemiringan talut 1:1,5 
Tabel 8.2 Harga-harga K dan n 225

Tabel 8.3 Berkurangnya Efisiensi Mesin 269

Tabel 8.4 Kebutuhan Bahan Bakar Maksimum Untuk Stasiun Pompa Yang Baik

Tabel 8.5 Harga-Harga C Yang Bergantung Kepada Kemiringan Saringan (Frank)

274

Tabel 9.1 Harga-harga $\xi \quad 284$

Tabel 9.2 Harga-Harga Perkiraan Untuk Koefisien Gesekan 296

Tabel 9.3 Harga-Harga Minimum Angka Rembesan Lane $\left(C_{L}\right) \quad 301$

Tabel 10.5 Skala Tebal Garis dan Tinggi Huruf 325

Tabel 10.9 Singkatan-singkatan yang digunakan dalam gambar

331

Tabel 10.1 Map Symbols - Simbol Peta 1

Tabel 10.2 Map Symbols - Simbol Peta 2

Tabel 10.3 Map Symbols - Simbol Peta 3 346

Tabel 10.4 Map Symbols - Simbol Peta $4 \quad 347$

Tabel 10.5 Map Symbols - Simbol Peta $5 \quad 348$

Tabel 10.6 Map Symbols - Simbol Peta 6

Tabel 10.7 Map Symbols - Simbol Peta 7 350

Tabel 10.9 Map Symbols - Simbol Peta $9 \quad 352$

Tabel 10.10 Map Symbols - Simbol Peta $10 \quad 353$

Tabel 10.11 Map Symbol - Simbols Peta 11

Tabel 10.12 Map Symbol - Simbol Peta 12

Tabel 10.13 Standar Hatching-Standar Arsiran 1 356

Tabel10.14 Standar Hatching-Standar Arsiran $2 \quad 357$

Tabel 10.15 Standar Hatching-Standar Arsiran $3 \quad 358$

Tabel 10.16 Simbol-simbol Penyelidikan Geologi Teknik dan Mekanika Tanah

(Symbol for Geotechnical and Soil Mechanical Investigation) 1

Tabel 10.17 Simbol-simbol Penyelidikan Geologi Teknik dan Mekanika Tanah

(Symbol for Geotechnical and Soil Mechanical Investigation) 2

Tabel 10.18. Simbol-simbol Penyelidikan Geologi Teknik dan Mekanika Tanah 
(Symbol for Geotechnical and Soil Mechanical

Investigation) 3

Tabel 10.19 Simbol-simbol Penyelidikan Geologi Teknik dan

Mekanika Tanah

(Symbol for Geotechnical and Soil Mechanical

Investigation) 4

Tabel 10.20 Simbol-simbol Penyelidikan Geologi Teknik dan

Mekanika Tanah

(Symbol for Geotechnical and Soil Mechanical

Investigation) 5

Tabel 10.21 Simbol-simbol Penyelidikan Geologi Teknik dan

Mekanika Tanah

(Symbol for Geotechnical and Soil Mechanical

Investigation) 6

Tabel 10.22 Simbol-simbol Penyelidikan Geologi Teknik dan

Mekanika Tanah

(Symbol for Geotechnical and Soil Mechanical

Investigation) 7

Tabel 10.23 Simbol-simbol Penyelidikan Geologi Teknik dan

Mekanika Tanah

(Symbol for Geotechnical and Soil Mechanical

Investigation) 8

Tabel 10.24 Simbol-simbol Penyelidikan Geologi Teknik dan

Mekanika Tanah

(Symbol for Geotechnical and Soil Mechanical

Investigation) 9

Tabel 10.25 Simbol-simbol Penyelidikan Geologi Teknik dan

Mekanika Tanah

(Symbol for Geotechnical and Soil Mechanical

Investigation) 10

Tabel 10.26 Simbol-simbol Penyelidikan Geologi Teknik dan

Mekanika Tanah

(Symbol for Geotechnical and Soil Mechanical

Investigation) 11

Tabel 10.27 Simbol-simbol Penyelidikan Geologi Teknik dan Mekanika Tanah 
(Symbol for Geotechnical and Soil Mechanical

Investigation) 12

Tabel 10.28 Simbol-simbol Penyelidikan Geologi Teknik dan

Mekanika Tanah

(Symbol for Geotechnical and Soil Mechanical

Investigation) 13

Tabel 10.29 Simbol-simbol Penyelidikan Geologi Teknik dan

Mekanika Tanah

(Symbol for Geotechnical and Soil Mechanical

Investigation) 14 


\section{DAFTAR GAMBAR}

Gambar 1.1 Definisi Daerah-Daerah Irigasi................................... 3

Gambar 1.2 Jaringan Irigasi Sederhana........................................... 9

Gambar 1.3 Jaringan Irigasi Semi Teknis ………........................... 10

Gambar 1.4 Jaringan Irigasi Teknis ........................................... 13

Gambar 1.5 Saluran-saluran primer dan sekunder ....................... 19

Gambar 1.6 Standar Sistem Tata Nama Untuk Skema

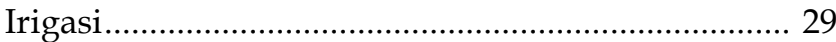

Gambar 1.7 Standar Sistem Tata Nama Untuk Bangunanbangunan Irigasi...................................................... 30

Gambar 1.8 Sistem tata nama petak rotasi dan kuarter.................. 31

Gambar 1.9 Sistem Tata Nama Jaringan Pembuang ..................... 32

Gambar 2.1 Petak Tersier Yang Ideal ........................................... 40

Gambar 2.2 Jalur-jalur Irigasi ...................................................... 41

Gambar 2.3 Sketsa Jalur-jalur Irigasi .............................................. 43

Gambar 2.4 Estimasi Jarak Antar Saluran Irigasi

dan Pembuang............................................................. 48

Gambar 2.5 Lay Out Irigasi Petak Tersier

Pada Kontur Terjal (1)............................................. 52

Gambar 2.6 Lay Out Irigasi Petak Tersier

Pada Kontur Terjal (2) ............................................... 53

Gambar 2.7 Kolam Olak Diujung Saluran Tersier

Dengan Aliran Super Kritis ......................................... 55

Gambar 2.8 Potongan Melintang Melaui Saluran Irigasi

Pembuang Kuarter .................................................... 56

Gambar 2.9 Lay Out Petak Tersier Pada Kontur

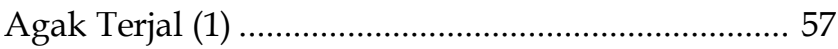

Gambar 2.10 Lay Out Petak Tersier Daerah Datar

Rawa-Rawa ............................................................ 59

Gambar 2.11 Lay Out Petak Tersier di Daerah

Bergelombang ............................................................... 61

Gambar 2.12 Lay Out Petak di Daerah Berawa-rawa..................... 62

Gambar 2.13 Lay Out Kolam Air Deras ........................................... 63

Gambar 2.14 Contoh Layout Jaringan Pipa ................................... 74

Gambar 2.15 Contoh Layout Detail Jaringan Irigasi Mini

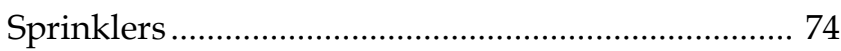

xiv 
Gambar 2.16 Contoh Tampak layout jaringan irigasi.................... 74

Gambar 2.17 Contoh Skema Pemberian Air Irigasi ...................... 75

Gambar 3.1 Saluran Dengan Bangunan Pengatur dan

Sadap Ke Saluran Sekunder

Gambar 3.2 Perubahan Debit Dengan Variasi Muka Air

Untuk Pintu Aliran Atas dan Aliran Bawah............. 85

Gambar 3.3 Saluran Sekunder Dengan Bangunan Pengatur

dan Sadap Ke Berbagai Arah

Gambar 3.4 Bangunan Pengatur : Pintu Aliran

Bawah Dengan Mercu Tetap...................................... 88

Gambar 3.5 Tata Letak Bangunan Bagi Sadap

Bentuk Menyamping ................................................... 93

Gambar 3.6 Tata Letak Bangunan Bagi Sadap

Bentuk Numbak ....................................................... 94

Gambar 3.7 Bangunan Sadap Pada Saluran Primer

dan Sekunder........................................................... 94

Gambar 4.1 Hubungan Timbal Balik Antara

Berbagai Taraf Termasuk Pembuatan

Rencana Induk ....................................................... 100

Gambar 4.2Urut-Urutan Kegiatan Proyek ..................................... 102

Gambar 4.3 Bagan Kegiatan-Kegiatan Pada

Tahap Studi dan Perencanaan ................................... 103

Gambar 4.4 Bagan Kegiatan-Kegiatan Pada Tahap

Studi dan Perencanaan (Lanjutan).............................. 104

Gambar 4.5 Bagan Kegiatan-Kegiatan Pada Tahap

Studi dan Perencanaan (Lanjutan).

Gambar 4.6 Bagan Kegiatan-Kegiatan Pada Tahap

Studi Detail Desain (lanjutan)

Gambar 5.1 Elevasi bangunan Sadap Tersier yang di

Perlukan

Gambar 5.2 Parameter Potongan Melintang Saluran

Travesium

Gambar 5.3 Tipe-Tipe Potongan Melintang

Gambar 5.4 Contoh Grafik Perhitungan Modulus Pembuang .... 147

Gambar 6.1 Analisis Double Mass................................................... 153

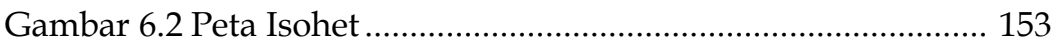


Gambar 6.3 Prosedur Perhitungan Banjir Rencana

Menggunakan Analisa Frekuensi (Pendekatan

Analisis) Untuk DAS Dengan Ketersediaan Data

$\geq 20$ Tahun

Gambar 6.4 Faktor frekuensi tumbuh

(frequency growth factors)............................................ 174

Gambar 6.5 Skema Simulasi Debit Metode Mock .......................... 179

Gambar 7.1 Alat Ukur Ambang Lebar .......................................... 205

Gambar 7.2 Alat Ukur Ambang Lebar Dengan

Pemasukan Bermuka Datar dan

Peralihan Penyempitan.............................................. 206

Gambar 7.3 C $C_{v}$ Sebagai Fungsi Perbandingan C da* / A1 ................ 207

Gambar 7.4 Ilustrasi Peristilahan yang Digunakan ....................... 208

Gambar 7.5 Dimensi Flum dan Alat Ukur.................................... 209

Gambar 7.6 Peralihan - peralihan Hilir ....................................... 210

Gambar 7.7 Bilangan - Bilangan Pengali Untuk Satuan

- Satuan yang Dipakai Pada

Papan Duga Miring.................................................... 211

Gambar 7.8 Alat Ukur Orifice Constan Head................................. 216

Gambar 8.1 Lebar Efektif Mercu................................................ 219

Gambar 8.2 Bentuk - Bentuk Mercu.............................................. 220

Gambar 8.3 Bendung dengan Mercu Bulat................................... 221

Gambar 8.4 Tekanan pada Mercu Bendung Bulat

Sebagai Fungsi Perbandingan $\mathrm{H}_{1} / \mathrm{r} \ldots \ldots \ldots \ldots \ldots \ldots \ldots \ldots \ldots . . . . . . . . . .222$

Gambar 8.5 Harga-harga Koefisien C0 untuk Bendung

Ambang Bulat Sebagai Fungsi

Perbandingan H1/r.............................................. 223

Gambar 8.6 Koefisien $\mathrm{C}_{1}$ sebagai fungsi perbandingan $\mathrm{P} / \mathrm{H}_{1} \ldots \ldots . .223$

Gambar 8.7 Harga-Harga Koefisien $C_{2}$ Untuk Bendung

Mercu Tipe Ogee Dengan Muka Hulu

Melengkung (Menurut USBR, 1960).

Gambar 8.8 Faktor Pengurangan Aliran Tenggelam

Sebagai Fungsi $\mathrm{H}_{2} / \mathrm{H}_{1}$

Gambar 8.9 Bentuk-bentuk bendung mercu Ogee

(U.S.Army Corps of Engineers,

Waterways Experimental Stasion) 
Gambar 8.10 Faktor koreksi untuk selain tinggi

energi rencana pada bendung mercu Ogee

(menurut Ven Te Chow, 1959, berdasarkan data

USBR dan WES).

Gambar 8.11 Faktor Pengurangan Aliran Tenggelam

Sebagai Fungsi $\mathrm{p}_{2} / \mathrm{H}_{1}$ dan $\mathrm{H}_{2} / \mathrm{H}_{1}$. (Disadur

dari US Army Corps of Engineers

Waterways Experimental Station)

228

Gambar 8.12 Harga-harga Cv sebagai Fungsi Perbandingan

Luas $1 \mathrm{Cd} \mathrm{A}$ / A1 Untuk Bagian Pengontrol

Segi Empat (dari Bos, 1977)

Gambar 8.13 Potongan Hulu dan Tampak Depan

Pengontrol 230

Gambar 8.14 Denah Pelimpah Bentuk Gergaji .............................. 232

Gambar 8.15 Pangkal Bendung................................................... 233

Gambar 8.16 Peredam Energi ....................................................... 234

Gambar 8.17 Metode Perencanaan Kolam Loncat Air................... 236

Gambar 8.18 Parameter-Parameter Loncat Air ............................. 238

Gambar 8.19 Hubungan Percobaan Antara Fr U,

$\mathrm{Y}_{2} / \mathrm{Yu}$ Untuk Ambang Ujung Pendek

(Menurut Forster dan Skrinde, 1950) ....................... 238

Gambar 8.20 Karakteristik Kolam Olak Untuk

Dipakai Dengan Bilangan Froude Di Atas............. 239

Gambar 8.21 Blok Halang Dan Blok-Blok Muka .......................... 240

Gambar 8.22 Peredam Energi Tipe Bak Tenggelam...................... 241

Gambar 8.23 Jari - Jari Minimum Bak.......................................... 242

Gambar 8.24 Grafik Batas Minimum Tinggi Air Hilir ................... 243

Gambar 8.25 Grafik dan Potongan Memanjang

Batas Maksimum Tinggi Air Hilir .......................... 244

Gambar 8.26 Kolam Olak Menurut Vlugter .................................. 244

Gambar 8.27 Potongan Memanjang Bendung

Tetap Dengan Peredam Energi Tipe MDO ............ 252

Gambar 8.28 Potongan Memanjang Bendung

Tetap Dengan Peredam Energi Tipe MDS ............. 252

Gambar 8.29 Grafik MDO - 1 Pengaliran Melalui

Mercu Bendung .................................................... 253 
Gambar 8.30 Grafik MDO - 1a Penentuan Bahaya

Kavitasi Di Hilir Mercu Bendung

Gambar 8.31 Grafik MDO - 2 Penentuan

Kedalaman Lantai Peredam Energi

Gambar 8.32 Grafik MDO - 3 Penentuan Panjang

Lantai Peredam Energi. 254

Gambar 8.33 Macam-Macam Tipe Pintu Bendung

Gerak Vertikal 260

Gambar 8.34 Tata letak dan Komponen Bendung Karet............... 262

Gambar 8.35 Potongan Melintang Bendung Karet ........................ 262

Gambar 8.36 Penampang Lintang Pada Pusat V-Notch................ 264

Gambar 8.37 Tampak Depan Tabung Karet yang

alami V-notch.......................................................... 264

Gambar 8.38 Tampak Depan Bendung Karet yang

ada di Kota Denpasar Bali ......................................... 264

Gambar 8.39 Loncat Air Di Hilir Bendung Karet.......................... 266

Gambar 8.40 Sketsa Panjang Lantai Hilir Untuk yi besar. ............ 266

Gambar 8.41 Koefisien Debitu Untuk Permukaan Pintu

Datar Atau Lengkung

Gambar 8.42 Variasi Dalam Perencanaan Roda

Sudut (Impeller), Kecepatan

Spesifik Dan Karakteristik Tinggi

Energi-Debit Pompa

Gambar 8.44 Tipe-Tipe Stasiun Pompa Tinggi

Energi Rendah.

Gambar 8.45 Tipe-Tipe Tata Letak Bendung

Saringan Bawah ....................................................... 273

Gambar 8.46 Hidrolika Saringan Bawah....................................... 274

Gambar 8.47 Aliran Bertekanan................................................. 275

Gambar 8.48 Penyelidikan Model Habermaas,

Yang Memperlihatkan Banyaknya Sedimen

Yang Masuk Ke Dalam Pengambilan ..................... 277

Gambar 8.49 Pintu Aliran Bawah ................................................ 278

Gambar 8.50 Koefisien K Untuk Debit Tenggelam

(Dari Schmidt) 
Gambar 9.1 Gaya Angkat Untuk Bangunan Yang

Dibangun Pada Pondasi Buatan

Gambar 9.2 Konstruksi Jaringan Aliran Menggunakan

Analog Listrik 285

Gambar 9.3 Contoh Jaringan Aliran Di Bawah Dam

Pasangan Batu Pada Pasir ...................................... 286

Gambar 9.4 Gaya Angkat Pada Pondasi Bendung........................ 287

Gambar 9.5 Distribusi Gempa Bumi dengan $M \geq 5,0$

di Wilayah Pulau Sumatera Tahun 2009 - 2017 290

Gambar 9.6 Unsur-Unsur Persamaan Distribusi

Tekanan Pada Pondasi................................................ 293

Gambar 9.7 Tebal Lantai Kolam Olak .............................................. 299

Gambar 9.8 Metode Angka Rembesan Lane ................................. 300

Gambar 9.9 Ujung Hilir Bangunan; Sketsa

Parameter-Parameter Stabilitas................................ 302

Gambar 9.10 Sketsa Gaya Tarik Pada Tabung Karet .................... 303

Gambar 9.11 Dinding Penahan Gravitasi

Dari Pasangan Batu 306

Gambar 9.12 Perlindungan Terhadap Rembesan

Melibat Pangkal Bendung ....................................... 307

Gambar 9.13 Lantai Hulu ............................................................... 309

Gambar 9.14 Dinding - Dinding Halang Di Bawah

Lantai Hulu Atau Tubuh Bendung........................... 310

Gambar 9.15 Alur Pembuang/Filter Di Bawah Kolam Olak ........ 311

Gambar 10.1 Ukuran-Ukuran Kertas dan Garis-Garis

Tepi Untuk Gambar .............................................. 317

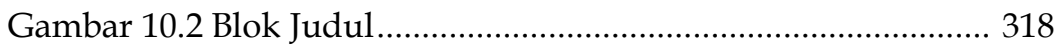

Gambar 10.3 Cara Mengisi Blok Judul .......................................... 319

Gambar 10.4 Tipe Gambar ....................................................... 320

Gambar 10.6 Tebal Garis Untuk Gambar-Gambar Bangunan ..... 326

Gambar 10.7 Penunjuk Skala ................................................... 327

Gambar 10.8 Ukuran dan Penunjuk ............................................... 330

Gambar 10.10 Blok Gambar Untuk Saluran-

Saluran Irigasi

Gambar 10.11 Blok Gambar Untuk Saluran-

Saluran Pembuang.............................................. 334 
Gambar 10.12 Blok Gambar Untuk Tanggul

Gambar 10.13 Tipe Tata Letak Gambar Pelaksanaan dan Gambar Potongan Memanjang 336

Gambar 10.14 Tipe-Tipe Tata Letak Gambar Potongan Melintang 1 337

Gambar 10.15 Tipe-Tipe Tata Letak Gambar Potongan Melintang 2......................................................... 338

Gambar 10.16 Blok Gambar Untuk Potongan Melintang.............. 339

Gambar 10.17 Leber Potongan Data Saluran................................... 339

Gambar 10.18 Pelipatan Gambar ................................................... 341 


\section{BAB I \\ DEFINISI, TUJUAN IRIGASI, SISTEM \\ JARINGAN IRIGASI DAN SUMBER \\ AIR IRIGASI}

\section{A. Definisi Irigasi}

Beberapa tahun terakhir, persoalan sumber daya air menjadi topik hangat dalam pembicaraan khalayak ramai, di samping pemberitaan masalah politik yang selalu hingar bingar di negeri ini. Berbagai bencana sumber daya air, mulai dari banjir tahunan atau banjir bandang, waduk jebol, tanah longsor, instrusi air laut, penurunan muka air atau kekeringan, sampai kebakaran lahan gambut seolah olah tidak hentihentinya menerpa dan terjadi silih berganti. Terjadinya bencana sumber daya air dapat disebabkan oleh faktor alam seperti: curah hujan berlebihan, bencana tsunami, dan banjir lahar akibat letusan gunung api atau gempa bumi. Namun, bencana juga dapat disebabkan oleh perilaku manusia yang tidak pantas dan berlebihan terhadap bumi. Pembabatan dan penggundulan hutan secara berlebihan, pemanenan air tanah yang melebihi imbangan pengisiannya, kegiatan tambang galian dan tambang-tambang lainya tanpa mengindahkan pelestarian lingkungan, semuanya itu dapat mengakibatkan kerusakan tubuh bumi dan akan merusak kehidupan manusia.(Okma Yendri, dkk, 2019).

Penggunaan Air di suatu Daerah Irigasi menjadi hal yang sangat penting agar sumber daya air yang ada dapat dialokasikan ke semua daerah irigasi secara efisien dan efektif. Pemberian air irigasi dan hujan akan mempengaruhi imbangan air di lahan. Bila diketahui ada kelebihan ketersediaan air terhadap kebutuhan air irigasi, maka dapat dilakukan penghematan dan dimanfaatkan lagi untuk berbagai kepentingan lain. Sistem imbangan air irigasi di lahan meliputi hujan, suplai air, kebutuhan air untuk tanaman dan kelebihan air perlu dikelola dengan baik dengan model simulasi untuk 
mengetahui besaran parameter-parameter dalam imbangan air di lahan irigasi dengan menerapkan secara koninyu, terjadwal dan terkontorol. (Okma Yendri dkk,2019)

Daerah Studi adalah Daerah Proyek ditambah dengan seluruh daerah aliran sungai (DAS) dan tempat-tempat pengambilan air ditambah dengan daerah-daerah lain yang ada hubungannya dengan daerah studi. Daerah Proyek adalah daerah di mana pelaksanaan pekerjaan dipertimbangkan dan/atau diusulkan dan daerah tersebut akan mengambil manfaat langsung dari proyek tersebut.

Daerah Irigasi Total/brutto adalah, daerah proyek dikurangi dengan perkampungan dan tanah-tanah yang dipakai untuk mendirikan bangunan daerah yang tidak diairi, jalan utama, rawa-rawa dan daerah-daerah yang tidak akan dikembangkan untuk irigasi di bawah proyek yang bersangkutan.

Daerah Irigasi Netto/Bersih adalah tanah yang ditanami (padi) dan ini adalah daerah total yang bisa diairi dikurangi dengan saluran-saluran irigasi dan pembuang primer, sekunder, tersier dan kuarter, jalan inspeksi, jalan setapak dan tanggul sawah. Daerah ini dijadikan dasar perhitungan kebutuhan air, panenan dan manfaat/ keuntungan yang dapat diperoleh dari proyek yang bersangkutan. Sebagai angka standar luas netto daerah yang dapat diairi diambil 0,9 kali luas total daerah-daerah yang dapat diairi.

Daerah Potensial adalah daerah yang mempunyai kemungkinan baik untuk dikembangkan. Luas daerah ini sama dengan Daerah lrigasi Netto tetapi biasanya belum sepenuhnya dikembangkan akibat terdapatnya hambatan-hambatan nonteknis.

Daerah Fungsional adalah bagian dari Daerah Potensial yang telah memiliki jaringan irigasi yang telah dikembangkan. Daerah fungsional luasnya sama atau lebih kecil dari Daerah Potensial

Irigasi adalah usaha penyediaan, pengaturan, dan pembuangan air irigasi untuk menunjang pertanian yang 
jenisnya meliputi irigasi permukaan, irigasi rawa, irigasi air bawah tanah, irigasi pompa, dan irigasi tambak Sistem irigasi meliputi prasarana irigasi, air irigasi, manajemen irigasi, kelembagaan pengelolaan irigasi, dan sumber daya manusia. Jaringan irigasi adalah saluran, bangunan, dan bangunan pelengkapnya yang merupakan satu kesatuan yang diperlukan untuk penyediaan, pembagian, pemberian, penggunaan, dan pembuangan air irigasi. Jaringan irigasi primer adalah bagian dari jaringan irigasi yang terdiri dari bangunan utama, saluran induk/primer, saluran pembuangannya, bangunan bagi, bangunan bagi-sadap, bangunan sadap, dan bangunan pelengkapnya. Jaringan irigasi sekunder adalah bagian dari jaringan irigasi yang terdiri dari saluran sekunder, saluran pembuangannya, bangunan bagi, bangunan bagisadap, bangunan sadap, dan bangunan pelengkapnya. (PP.No.20 tahun 2006).

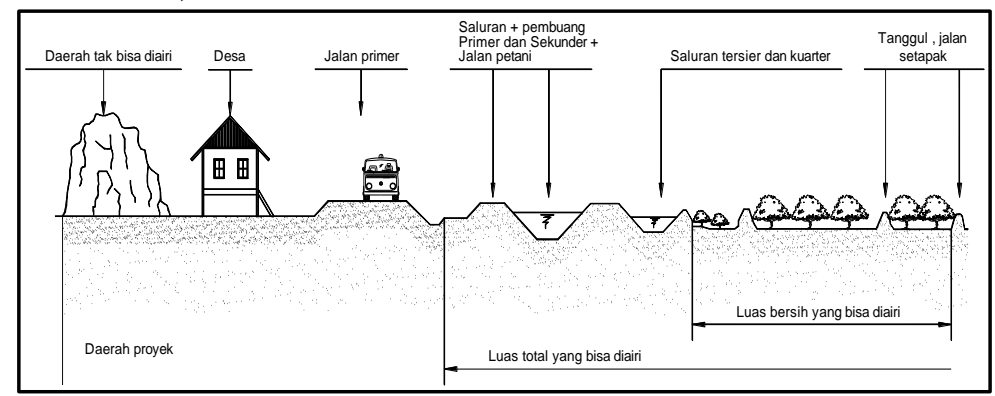

Gambar 1.1. Definisi Daerah-Daerah Irigasi

Sumber : Standar Perencanan Irigasi KP.01,2010

\section{B. Tujuan dan Manfaat Irigasi}

Banyanknya air yang terbuang menyebabkan tidak efisienya penggunaan air, kelebihan air akibat curah hujan yang berlebihan akan tejadi banjir, Tanaman padi yang tegenang air dalam waktu lama apabila tidak diatur dengan baik maka tanaman padi akan membusuk dan mati, bila kekurangan air tanaman padi tidak subur selanjutnya mati.(Okma Yendri 2020). Menurut Christa Emanuel 
Sembiring,2016, secara garis besar, tujuan irigasi dapat digolongkan menjadi 2 (dua) golongan, yaitu :

1. Tujuan Langsung, yaitu irigasi mempunyai tujuan untuk membasahi tanah berkaitan dengan kapasitas kandungan air dan udara dalam tanah sehingga dapat dicapai suatu kondisi yang sesuai dengan kebutuhan untuk pertumbuhan tanaman yang ada di tanah tersebut.

2. Tujuan Tidak Langsung, yaitu irigasi mempunyai tujuan yang meliputi mengatur suhu dari tanah, mencuci tanah yang mengandung racun, mengangkut bahan pupuk dengan melalui aliran air yang ada, menaikkan muka air tanah, meningkatkan elevasi suatu daerah dengan cara mengalirkan air dan mengendapkan lumpur yang terbawa air, dan lain sebagainya

Menurut Standar Perencanaan Irigasi KP-01 irigasi adalah sistem pemberian air ketanah-tanah pertanian guna mencukupi kebutuhan tanaman agar tanaman tersebut tumbuh dengan baik. Adapun tujuan irigasi adalah sebagai berikut:

1. Membasahi tanaman. Membasahi tanah dengan menggunakan air irigasi bertujuan memenuhi kekurangan air di daerah pertanian pada saat air hujan kurang atau tidak ada. Hal ini penting sekali karena kekurangan air yang di perlukan untuk tumbuh dapat mempengaruhi hasil panen tanaman tersebut.

2. Merabuk. Merabuk adalah pemberian air yang tujuannya selain membasahi juga memberi zat-zat yang berguna bagi tanaman itu sendiri.

3. Mengatur suhu. Tanaman dapat tumbuh dengan baik pada suhu yang tidak terlalu tinggi dan tidak terlalu rendah, sesuai dengan jenis tanamannya.

4. Membersihkan tanah atau memberantas hama. Maksud irigasi juga bertujuan untuk membasmi hama-hama yang berada dan bersarang dalam tanah dan membahayakan bagi tanaman sehingga pada musim kemarau sebaiknya sawah diberikan air agar sifat garamnya hilang. 
5. Kolmatase. Kolmatase adalah pengairan dengan maksud memperbaiki/meninggikan permukaan tanah.

6. Menambah persediaan air tanah. Tujuan bermaksud menambah persediaan air tanah untuk keperluan seharihari. Biasanya dilakukan dengan cara menahan air di suatu tempat, sehingga memberikan kesempatan pada air tersebut untuk meresap ke dalam tanah yang pada akhirnya dimanfaatkan oleh yang memerlukan.

Irigasi sangat dibutuhkan untuk pertanian, perkebunan dan lain-lainnya. Adapun manfaat irigasi adalah sebagai berikut:

1. Menambahkan air ke dalam tanah untuk menyediakan cairan yang diperlukan untuk pertumbuhan tanaman.

2. Untuk menyediakan jaminan panen pada saat musim kemarau pendek.

3. Untuk mendinginkan tanah dan atmosfer, sehingga menimbulkan lingkungan yang baik untuk pertumbuhan tanamam.

4. Untuk mencuci dan mengurangi garam tanah.

5. Untuk mengurangi bahaya erosi tanah.

6. Untuk melunakkan pembajakan dan gumpalan tanah.

\section{Tingkat-tingkat Jaringan Irigasi}

Tingkat jaringan irgasi berdasarkan cara pengaturan pengukuran aliran air dan lengkapnya fasilitas, jaringan irigasi dapat dibedakan ke dalam tiga tingkatan lihat Tabel 1.1 yakni:

1. Sederhana

2. Semiteknis, atau

3. Teknis.

Ketiga tingkatan tersebut diperlihatkan pada Gambar 1.1, 1.2 dan 1.3. 
Tabel 1.1 Tingktat Jaringan Irigasi

\begin{tabular}{|c|c|c|c|c|}
\hline & \multicolumn{3}{|c|}{ Klasifikasi jaringan irigasi } \\
\hline & & Teknis & Semiteknis & Sederhana \\
\hline 1 & Bangunan Utama & Bangunan permanen & $\begin{array}{l}\text { Bangunan permanen } \\
\text { atau semi permanen }\end{array}$ & Bangunan sementara \\
\hline 2 & $\begin{array}{l}\text { Kemampuan bangunan } \\
\text { dalam mengukur dan } \\
\text { mengatur debit }\end{array}$ & Baik & Sedang & Jelek \\
\hline 3 & Jaringan saluran & $\begin{array}{l}\text { Saluran irigasi dan } \\
\text { pembuang terpisah }\end{array}$ & $\begin{array}{l}\text { Saluran irigasi dan } \\
\text { pembuang tidak } \\
\text { sepenuhnya terpisah }\end{array}$ & $\begin{array}{l}\text { Saluran irigasi dan } \\
\text { pembuang jadi satu }\end{array}$ \\
\hline 4 & Petak tersier & $\begin{array}{l}\text { Dikembangkan } \\
\text { sepenuhnya }\end{array}$ & $\begin{array}{l}\text { Belum dikembangkan } \\
\text { atau densitas bangunan } \\
\text { tersier jarang }\end{array}$ & $\begin{array}{l}\text { Belum ada jaringan } \\
\text { terpisah yang } \\
\text { dikembangkan }\end{array}$ \\
\hline 5 & $\begin{array}{l}\text { Efisiensi secara } \\
\text { keseluruhan }\end{array}$ & $\begin{array}{l}\text { Tinggi } \\
50-60 \% \\
\text { (Ancar-ancar) }\end{array}$ & $\begin{array}{l}\text { Sedang } \\
40-50 \% \\
\text { (Ancar-ancar) }\end{array}$ & $\begin{array}{l}\text { Kurang } \\
<40 \% \\
\text { (Ancar-ancar }\end{array}$ \\
\hline 6 & Ukuran & Tak ada batasan & Sampai 2.000 ha & Tak lebih dari 500 ha \\
\hline 7 & Jalan Usaha Tani & Ada ke seluruh areal & Hanya sebagian areal & Cenderung tidak ada \\
\hline 8 & Kondisi $\mathrm{O} \& \mathrm{P}$ & - Ada instansi yang & Belum teratur & Tidak ada \\
\hline
\end{tabular}




\begin{tabular}{|l|l|l|l|l|}
\hline & menangani & & O \& P \\
& - Dilaksanakan & & \\
teratur & & \\
\hline
\end{tabular}

Sumber : Standar Perencanan Irigasi KP.01,2010 
Untuk konteks Standarisasi Irigasi, hanya irigasi teknis saja yang ditinjau. Bentuk irigasi yang lebih maju ini cocok untuk dipraktekkan di sebagian besar pembangunan irigasi di Indonesia. Jaringan irigasi dapat dibedakan adanya empat unsur fungsional pokok, yaitu:

1. Bangunan-bangunan utama (headworks) di mana air diambil dari sumbernya, umumnya sungai atau waduk,

2. Jaringan pembawa berupa saluran yang mengalirkan air irigasi ke petak-petak tersier,

3. Petak-petak tersier dengan sistem pembagian air dan sistem pembuangan kolektif, air irigasi dibagi-bagi dan dialirkan kesawah-sawah dan kelebihan air ditampung di dalam suatu sistem pembuangan di dalam petak tersier;

4. Sistem pembuang berupa saluran dan bangunan bertujuan untuk membuang kelebihan air dari sawah ke sungai atau saluran-saluran alamiah.

\section{Irigasi Sederhana}

Irigasi sederhana, lihat gambar 1.1 pembagian air tidak diukur atau diatur, air lebih akan mengalir ke saluran pembuang. Para petani pemakai air itu tergabung dalam satu kelompok jaringan irigasi yang sama, sehingga tidak memerlukan keterlibatan pemerintah di dalam organisasi jaringan irigasi semacam ini. Persediaan air biasanya berlimpah dengan kemiringan berkisar antara sedang sampai curam. Oleh karena itu hampir-hampir tidak diperlukan teknik yang sulit untuk sistem pembagian airnya. Jaringan irigasi yang masih sederhana itu mudah diorganisasi tetapi memiliki kelemahan-kelemahan yang serius. Pertama-tama, ada pemborosan air dan, karena pada umumnya jaringan ini terletak di daerah yang tinggi, air yang terbuang itu tidak selalu dapat mencapai daerah rendah yang lebih subur. Kedua, terdapat banyak penyadapan yang memerlukan lebih banyak biaya lagi dari penduduk karena setiap desa membuat jaringan dan pengambilan sendiri-sendiri. Karena bangunan pengelaknya 
bukan bangunan tetap/permanen, maka umurnya mungkin pendek.

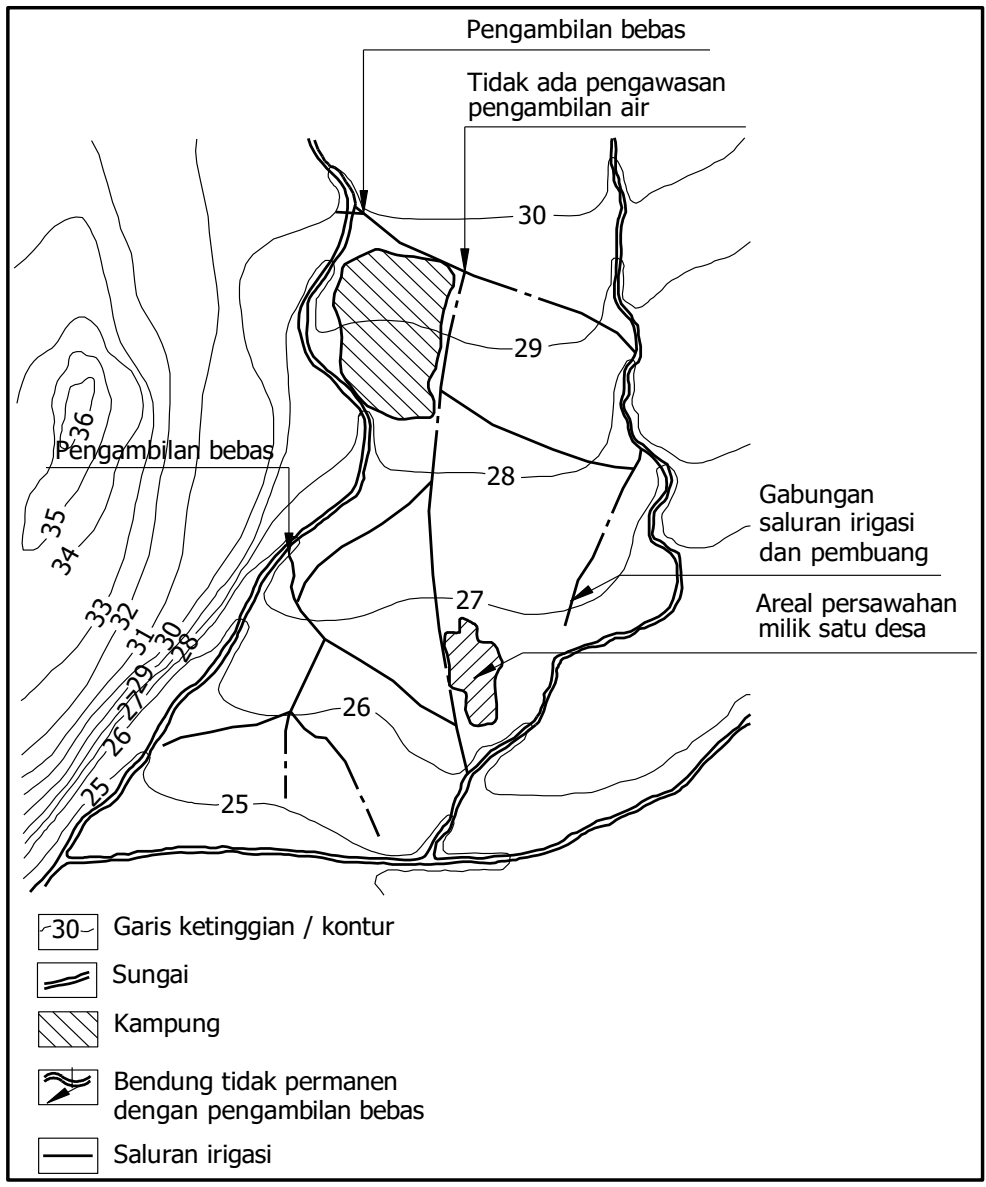

Gambar 1.2 Jaringan Irigasi Sederhana

Sumber : Standar Perencanan Irigasi KP.01,2010

\section{Jaringan Irigasi Semiteknis}

Perbedaan satu-satunya antara jaringan irigasi sederhana dan jaringan semiteknis adalah bahwa jaringan semiteknis ini bendungnya terletak di sungai lengkap dengan bangunan pengambilan dan bangunan pengukur di bagian hilirnya. Mungkin juga dibangun beberapa bangunan 
permanen di jaringan saluran. Sistem pembagian air biasanya serupa dengan jaringan sederhana (Gambar 1.2). Adalah mungkin bahwa pengambilan dipakai untuk melayani/mengairi daerah yang lebih luas dari daerah layanan pada jaringan sederhana. Oleh karena itu biayanya ditanggung oleh lebih banyak daerah layanan. Organisasinya akan lebih rumit jika bangunan tetapnya berupa bangunan pengambilan dari sungai, karena diperlukan lebih banyak keterlibatan dari pemerintah, dalam hal ini Departemen Pekerjaan Umum.

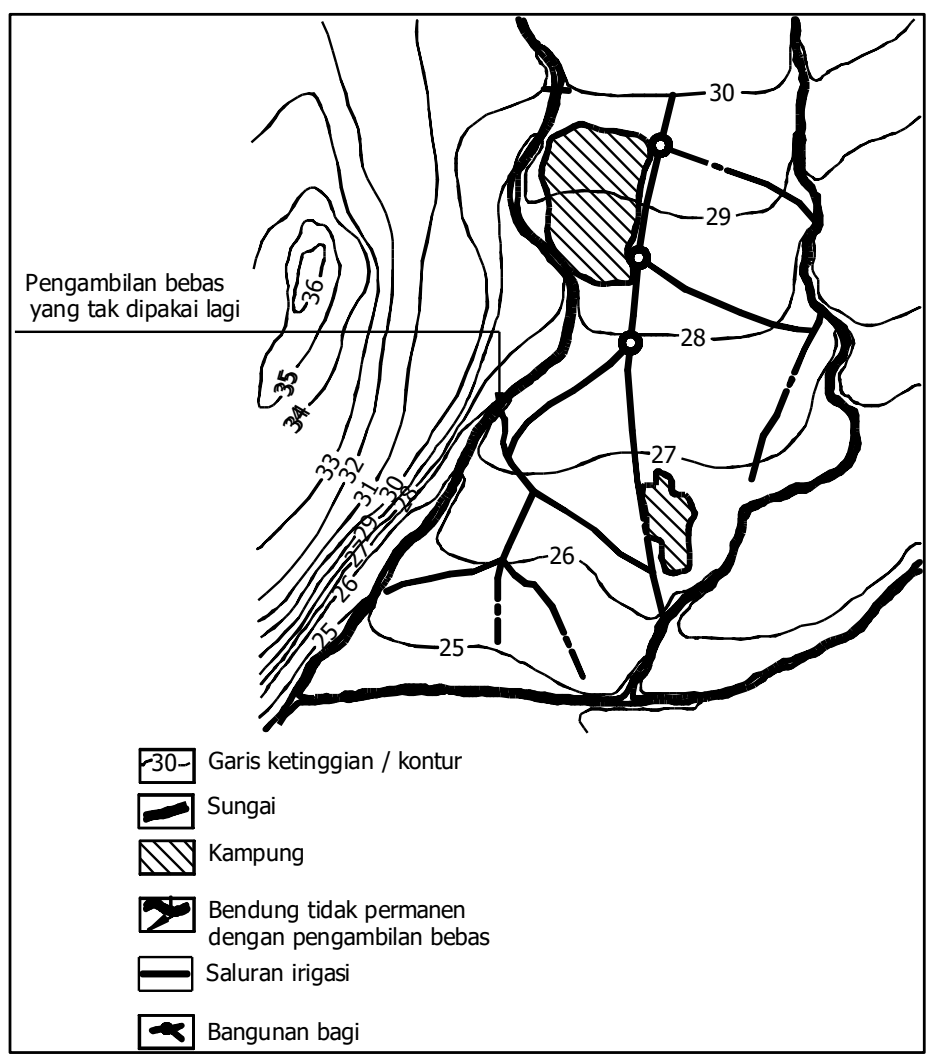

Gambar 1.3 Jaringan Irigasi Semi Teknis

Sumber : Standar Perencanan Irigasi KP.01,2010 


\section{Jaringan Irigasi Teknis}

Prinsip dalam perencanaan jaringan teknis adalah pemisahan antara jaringan irigasi dan jaringan pembuang/pematus. Hal ini berarti bahwa baik saluran irigasi maupun pembuang tetap bekerja sesuai dengan fungsinya masing-masing, dari pangkal hingga ujung. Saluran irigasi mengalirkan air irigasi ke sawah-sawah dan saluran pembuang mengalirkan air lebih dari sawah-sawah ke saluran pembuang alamiah yang kemudian akan diteruskan ke laut (Gambar 1.3).

Petak tersier menduduki fungsi sentral dalam jaringan irigasi teknis. Sebuah petak tersier terdiri dari sejumlah sawah dengan luas keseluruhan yang idealnya maksimum 50 ha, tetapi dalam keadaan tertentu masih bisa ditolerir sampai seluas 75 ha. Perlunya batasan luas petak tersier yang ideal hingga maksimum adalah agar pembagian air di saluran tersier lebih efektif dan efisien hingga mencapai lokasi sawah terjauh.

Permasalahan yang banyak dijumpai di lapangan untuk petak tersier dengan luasan lebih dari 75 ha antara lain:

1. dalam proses pemberian air irigasi untuk petak sawah terjauh sering tidak terpenuhi.

2. kesulitan dalam mengendalikan proses pembagian air sehingga sering terjadi pencurian air,

3. banyak petak tersier yang rusak akibat organisasi petani setempat yang tidak terkelola dengan baik.

Semakin kecil luas petak dan luas kepemilikan maka semakin mudah organisasi setingkat P3A/GP3A untuk melaksanakan tugasnya dalam melaksanakan operasi dan pemeliharaan. Petak tersier menerima air di suatu tempat dalam jumlah yang sudah diukur dari suatu jaringan pembawa yang diatur oleh Institusi Pengelola Irigasi. Pembagian air di dalam petak tersier diserahkan kepada para petani. Jaringan saluran tersier dan kuarter 
mengalirkan air ke sawah. Kelebihan air ditampung di dalam suatu jaringan saluran pembuang tersier dan kuarter dan selanjutnya dialirkan ke jaringan pembuang primer.

Jaringan irigasi teknis yang didasarkan pada prinsipprinsip di atas adalah cara pembagian air yang paling efisien dengan mempertimbangkan waktu merosotnya persediaan air serta kebutuhan-kebutuhan pertanian. Jaringan irigasi teknis memungkinkan dilakukannya pengukuran aliran, pembagian air irigasi dan pembuangan air lebih secara efisien. Jika petak tersier hanya memperoleh air pada satu tempat saja dari jaringan (pembawa) utama, hal ini akan memerlukan jumlah bangunan yang lebih sedikit di saluran primer, eksploitasi yang lebih baik dan pemeliharaan yang lebih murah dibandingkan dengan apabila setiap petani diizinkan untuk mengambil sendiri air dari jaringan pembawa. Kesalahan dalam pengelolaan air di petak-petak tersier juga tidak akan mempengaruhi pembagian air di jaringan utama.

Untuk memdibuat sistem gabungan (fungsi saluran irigasi dan pembuang digabung). Walaupun jaringan ini memiliki keuntungan tersendiri, dan kelemahankelemahannya juga amat serius sehingga sistem ini pada umumnya tidak akan diterapkan. Keuntungan yang dapat diperoleh dari jaringan gabungan semacam ini adalah pemanfaatan air yang lebih ekonomis dan biaya pembuatan saluran lebih rendah, karena saluran pembawa dapat dibuat lebih pendek dengan kapasitas yang lebih kecil. Kelemahankelemahannya antara lain adalah bahwa jaringan semacam ini lebih sulit diatur dan dioperasikan sering banjir, lebih cepat rusak dan menampakkan pembagian air yang tidak merata. Bangunan-bangunan tertentu di dalam jaringan tersebut akan memiliki sifat-sifat seperti bendung dan relatif mahal. 


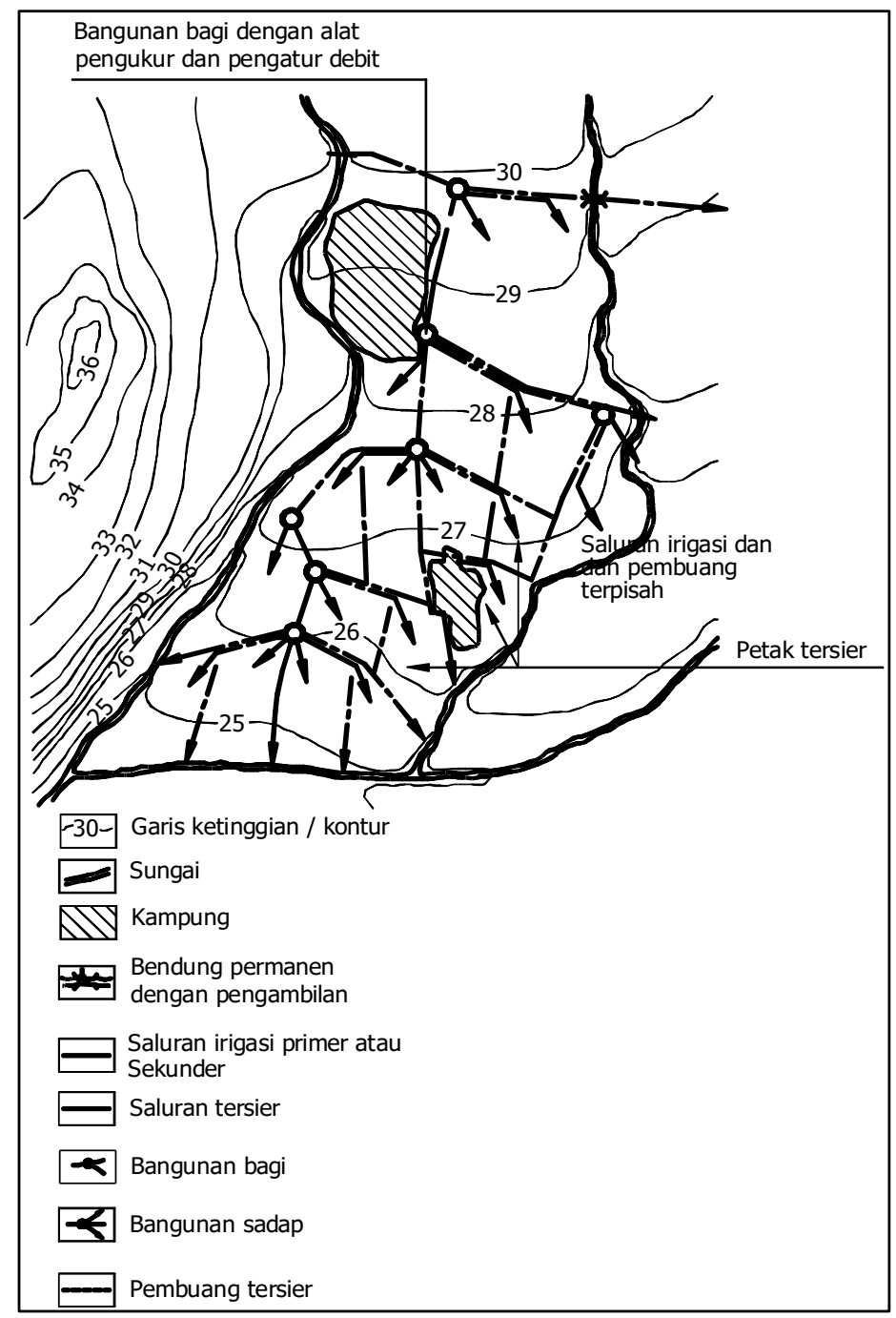

\section{Gambar 1.3 Jaringan Irigasi Teknis}

Sumber: Standar Perencanan Irigasi KP.01,2010

\section{Petak Irigasi}

\section{Pendahuluan}

Dalam bab ini membicarakan berbagai unsur sebuah jaringan irigasi teknis, yang selanjutnya hanya akan disebut "jaringan irigasi" , akan diberikan definisi praktis mengenai 
petak primer, sekunder dan tersier. Bangunan dibagi-bagi menurut fungsinya dan akan dijelaskan juga pemakaiannya. Rekomendasi/anjuran mengenai pemilihan tipe bangunan pengukur dan pengatur diberikan dalam bab ini. Penjelasan yang lebih terinci akan diberikan dalam bagian-bagian Kriteria Perencanaan lainnya.

Uraian fungsional umum mengenai unsur-unsur jaringan irigasi akan merupakan bimbingan bagi para perekayasa dalam menyiapkan perencanaan tata letak dan jaringan irigasi.

\section{Petak Ikhtisar}

Peta ikhtisar merupakan informasi berbagai macam bagian dari suatu jaringan irigasi yang saling berhubungan. Peta ikhtisar tersebut dapat dilihat pada peta tata letak.

Peta ikhtisar irigasi tersebut memperlihatkan :
a. Bangunan-bangunan utama
b. Jaringan dan trase saluran irigasi
c. Jaringan dan trase saluran pembuang
d. Petak-petak primer, sekunder dan tersier
e. Lokasi bangunan
f. Batas-batas daerah irigasi
g. Jaringan dan trase jalan
h. Daerah-daerah yang tidak diairi (misal desa-desa)
i. Daerah-daerah yang tidak dapat diairi (tanah jelek, terlalu tinggi dsb).

Peta Petak Ikhtisar dibuat berdasarkan peta topografi yang dilengkapi dengan garis-garis kontur dengan skala 1:25.000. Peta ikhtisar detail yang biasa disebut peta petak, dipakai untuk perencanaan dibuat dengan skala 1:5.000, dan untuk petak tersier 1:5.000 atau 1:2.000.

\section{Petak Tersier}

Dasar perencanaan yang berkenaan dengan unit tanah adalah petak tersier. Petak ini menerima air irigasi yang dialirkan dan diukur pada bangunan sadap (off take) tersier yang menjadi tanggung jawab Dinas Pengairan. 
Bangunan sadap tersier mengalirkan airnya ke saluran tersier. Di petak tersier pembagian air, eksploitasi dan pemeliharaan menjadi tanggung jawab para petani yang bersangkutan, di bawah bimbingan pemerintah. Ini juga menentukan ukuran petak tersier. Petak yang kelewat besar akan mengakibatkan pembagian air menjadi tidak efisien. Faktor-faktor penting lainnya adalah jumlah petani dalam satu petak, jenis tanaman dan topografi. Di daerah-daerah yang ditanami padi luas petak tersier idealnya maksimum 50 ha, tapi dalam keadaan tertentu dapat ditolelir sampai seluas 75 ha, disesuaikan dengan kondisi topografi dan kemudahan eksploitasi dengan tujuan agar pelaksanaan Operasi dan Pemeliharaan lebih mudah. Petak tersier harus mempunyai batas-batas yang jelas seperti misalnya parit, jalan, batas desa dan batas perubahan bentuk medan (terrain fault).

Petak tersier dibagi menjadi petak-petak kuarter, masing- masing seluas kurang lebih $8-15$ ha. Apabila keadaan topografi. memungkinkan, bentuk petak tersier sebaiknya bujur sangkar atau segi empat untuk mempermudah pengaturan tata letak dan memungkinkan pembagian air secara efisien.Petak tersier harus terletak langsung berbatasan dengan saluran sekunder atau saluran primer. Perkecualian: kalau petak-petak tersier tidak secara langsung terletak di sepanjang jaringan saluran irigasi utama yang dengan demikian, memerlukan saluran tersier yang membatasi petak-petak tersier lainnya, hal ini harus dihindari. Panjang saluran tersier sebaiknya kurang dari $1.500 \mathrm{~m}$, tetapi dalam kenyataan kadang-kadang panjang saluran ini mencapai $2.500 \mathrm{~m}$. Panjang saluran kuarter lebih baik di bawah $500 \mathrm{~m}$, tetapi prakteknya kadang-kadang sampai $800 \mathrm{~m}$.

\section{Petak Sekunder}

Petak sekunder menerima air dari bangunan bagi yang terletak di saluran primer atau sekunder. Petak sekunder terdiri dari beberapa petak tersier yang 
kesemuanya dilayani oleh satu saluran sekunder. Batasbatas petak sekunder pada umumnya berupa tanda-tanda topografi yang jelas, seperti misalnya saluran pembuang. Luas petak sekunder bisa berbeda-beda, tergantung pada situasi daerah. Saluran sekunder sering terletak di punggung medan mengairi kedua sisi saluran hingga saluran pembuang yang membatasinya. Saluran sekunder boleh juga direncana sebagai saluran garis tinggi yang mengairi lereng-lereng medan yang lebih rendah saja.

\section{Petak Primer}

Petak primer dilayani oleh satu saluran primer yang mengambil airnya langsung dari sumber air, biasanya sungai. Petak primer terdiri dari beberapa petak sekunder, yang mengambil air langsung dari saluran primer. Proyekproyek irigasi tertentu mempunyai dua saluran primer. Ini menghasilkan dua petak primer. Daerah di sepanjang saluran primer sering tidak dapat dilayani dengan mudah dengan cara menyadap air dari saluran sekunder. Apabila saluran primer melewati sepanjang garis tinggi, daerah saluran primer yang berdekatan harus dilayani langsung dari saluran primer.

\section{E. Konstruksi Irigasi}

Konsruksi irigasi adalah sebagai kompleks bangunan yang direncanakan di dan sepanjang sungai atau aliran air untuk membelokkan air ke dalam jaringan saluran agar dapat dipakai untuk keperluan irigasi. Bangunan utama bisa mengurangi kandungan sedimen yang berlebihan, serta mengukur banyaknya air yang masuk. Bangunan utama terdiri dari bendung dengan peredam energi, satu atau dua pengambilan utama pintu bilas kolam olak dan (jika diperlukan) kantong lumpur, tanggul banjir pekerjaan sungai dan bangunan-bangunan pelengkap. Berikut ini akan dijelaskan sebagai berikt :

\section{Bendung Gerak}

Bendung (weir) atau bendung gerak (barrage) dugunakan untuk meninggikan muka air di sungai sampai 
pada ketinggian yang diperlukan agar air dapat dialirkan ke saluran irigasi dan petak tersier. Ketinggian itu akan menentukan luas daerah yang diairi (command area) Bendung gerak adalah bangunan yang dilengkapi dengan pintu yang dapat dibuka untuk mengalirkan air pada waktu terjadi banjir besar dan ditutup apabila aliran kecil. Di Indonesia, bendung adalah bangunan yang paling umum dipakai untuk membelokkan air sungai untuk keperluan irigasi.

\section{Bendung Karet}

Bendung karet memiliki dua bagian pokok seperti tubuh bendung yang terbuat dari karet dan pondasi beton berbentuk plat beton sebagai dudukan tabung karet serta dilengkapi satu ruang kontrol dengan beberapa perlengkapan (mesin) untuk mengontrol mengembang dan mengempisnya tabung karet. Bendung berfungsi meninggikan muka air dengan cara mengembangkan tubuh bendung dan menurunkan muka air dengan cara mengempiskan tubuh bendung yang terbuat dari tabung karet dapat diisi dengan udara atau air. Proses pengisian udara atau air dari pompa udara atau air dilengkapi dengan instrumen pengontrol udara atau air (manometer).

\section{Pengambilan Bebas}

Pengambilan bebas merupakan bangunan yang dibuat di tepi sungai yang mengalirkan air sungai ke dalam jaringan irigasi, tanpa mengatur tinggi muka air di sungai. Dalam keadaan demikian, jelas bahwa muka air di sungai harus lebih tinggi dari daerah yang diairi dan jumlah air yang dibelokkan harus dapat dijamin cukup

\section{Pengambilan dari Waduk}

Waduk (reservoir) berfungsi menampung air irigasi pada waktu terjadi surplus air di sungai agar dapat dipakai sewaktu-waktu terjadi kekurangan air. Jadi, fungsi utama waduk adalah untuk mengatur aliran sungai. Waduk yang berukuran besar sering mempunyai banyak fungsi seperti untuk keperluan irigasi, tenaga air pembangkit listrik, 
pengendali banjir, perikanan dsb. Waduk yang berukuran lebih kecil dipakai untuk keperluan irigasi saja.

\section{Stasiun Pompa}

Pada mulanya irigasi pompa hanya memerlukan modal kecil, tetapi biaya eksploitasinya mahal. lrigasi dengan pompa bisa dipakai apabila pengambilan secara gravitasi temyata tidak layak dilihat dari segi teknis maupun ekonomis.

\section{Saluran Irigasi}

Saluran irigasi utama terdiri dari :

a. Saluran primer membawa air dari bendung ke saluran sekunder dan ke petak-petak tersier yang diairi. Batas ujung saluran primer adalah pada bangunan bagi yang terakhir, lihat juga Gambar 1.4.

b. Saluran sekunder membawa air dari saluran primer ke petak-petak tersier yang dilayani oleh saluran sekunder tersebut. Batas ujung saluran ini adalah pada bangunan sadap terakhir.

c. Saluran pembawa membawa air irigasi dari sumber air lain (bukan sumber yang memberi air pada bangunan utama proyek) ke jaringan irigasi primer.

Jaringan saluran irigasi tersier

a. Saluran tersier membawa air dari bangunan sadap tersier di jaringan utama ke dalam petak tersier lalu ke saluran kuarter. Batas ujung saluran ini adalah boks bagi kuarter yang terakhir

b. Saluran kuarter membawa air dari boks bagi kuarter melalui bangunan sadap tersier atau parit sawah ke sawah-sawah

c. Perlu dilengkapi jalan petani ditingkat jaringan tersier dan kuarter sepanjang itu memang diperlukan oleh petani setempat dan dengan persetujuan petani setempat pula, karena banyak ditemukan di lapangan jalan petani yang rusak sehingga akses petani dari dan ke sawah menjadi terhambat, terutama untuk petak sawah yang paling ujung. 
d. Pembangunan sanggar tani sebagai sarana untuk diskusi antar petani sehingga partisipasi petani lebih meningkat, dan pembangunannya disesuaikan dengan kebutuhan dan kondisi petani setempat serta diharapkan letaknya dapat mewakili wilayah P3A atau GP3A setempat.

e. Saluran muka tersier membawa air dari bangunan sadap tersier ke petak tersier yang terletak di seberang petak tersier lainnya. Saluran ini termasuk dalam wewenang dinas irigasi dan oleh sebab itu pemeliharaannya menjadi tanggung jawabnya.

Garis Sempadan Saluran

Dalam rangka pengamanan saluran dan bangunan maka perlu ditetapkan garis sempadan saluran dan bangunan irigasi yang jauhnya ditentukan dalam peraturan perundangan sempadan saluran.

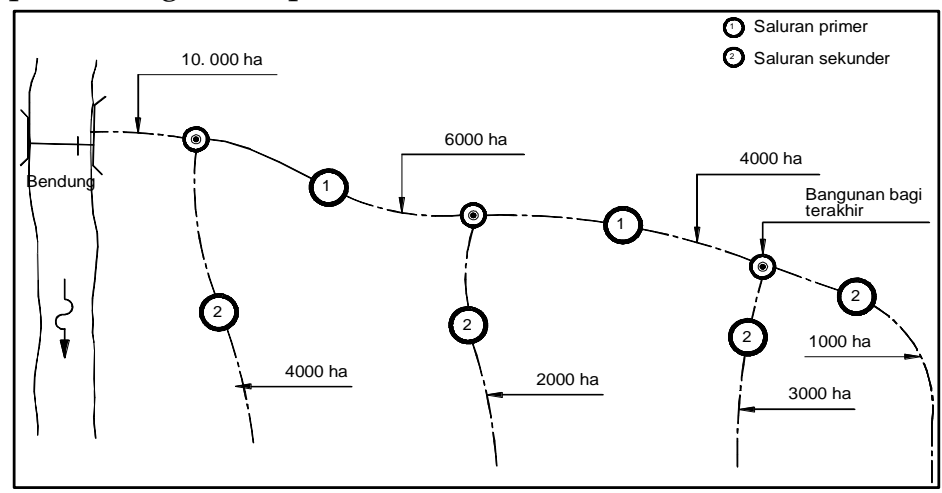

Gambar 1.4. Saluran-Saluran Primer dan Sekunder

Sumber : Standar Perencanan Irigasi KP.01,2010

\section{Saluran Pembuang}

Jaringan saluran pembuang tersier

a. Saluran pembuang kuarter terletak di dalam satu petak tersier, menampung air langsung dari sawah dan membuang air tersebut ke dalam saluran pembuang tersier.

b. Saluran pembuang tersier terletak di dan antara petakpetak tersier yang termasuk dalam unit irigasi sekunder 
yang sama dan menampung air, baik dari pembuang kuarter maupun dari sawah-sawah. Air tersebut dibuang ke dalam jaringan pembuang sekunder.

Jaringan saluran pembuang utama

a. Saluran pembuang sekunder menampung air dari jaringan pembuang tersier dan membuang air tersebut ke pembuang primer atau langsung ke jaringan pembuang alamiah dan ke luar daerah irigasi.

b. Saluran pembuang primer mengalirkan air lebih dari saluran pembuang sekunder ke luar daerah irigasi. Pembuang primer sering berupa saluran pembuang alamiah yang mengalirkan kelebihan air tersebut ke sungai, anak sungai atau ke laut

\section{Bangunan Bagi dan Sadap}

Bangunan bagi dan sadap pada irigasi teknis dilengkapi dengan pintu dan alat pengukur debit untuk memenuhi kebutuhan air irigasi sesuai jumlah dan pada waktu tertentu. Namun dalam keadaan tertentu sering dijumpai kesulitan-kesulitan dalam operasi dan pemeliharaan sehingga muncul usulan sistem proporsional. Yaitu bangunan bagi dan sadap tanpa pintu dan alat ukur tetapi dengan syarat-syarat sebagai berikut:

a. Elevasi ambang ke semua arah harus sama

b. Bentuk ambang harus sama agar koefisien debit sama.

c. Lebar bukaan proporsional dengan luas sawah yang diairi.

Untuk menetapkan agar diterapkan tetap memakai pintu dan alat ukur debit dengan memenuhi kreteria dibawah ini :

a. Bangunan bagi terletak di saluran primer dan sekunder pada suatu titik cabang dan berfungsi untuk membagi aliran antara dua saluran atau lebih.

b. Bangunan sadap tersier mengalirkan air dari saluran primer atau sekunder ke saluran tersier penerima. 
c. Bangunan bagi dan sadap mungkin digabung menjadi satu rangkaian bangunan.

d. Boks-boks bagi di saluran tersier membagi aliran untuk dua saluran atau lebih (tersier, subtersier dan/atau kuarter).

\section{Bangunan-bangunan Pengukur dan Pengatur}

Aliran akan diukur di hulu saluran primer, di cabang saluran jaringan primer dan di bangunan sadap sekunder maupun tersier. Bangunan ukur dapat dibedakan menjadi bangunan ukur aliran atas bebas (free overflow) dan bangunan ukur alirah bawah (underflow). Beberapa dari bangunan pengukur dapat juga dipakai untuk mengatur aliran air.

Bangunan ukur yang dapat dipakai ditunjukkan pada Tabel 1.2

Tabel 1.2 Alat-Alat Ukur Irigasi

\begin{tabular}{|l|c|c|}
\hline \multicolumn{1}{|c|}{ Tipe } & $\begin{array}{c}\text { Mengukur } \\
\text { dengan }\end{array}$ & Mengatur \\
\hline $\begin{array}{l}\text { Bangunan ukur } \\
\text { Ambang lebar }\end{array}$ & $\begin{array}{c}\text { Aliran } \\
\text { Atas }\end{array}$ & Tidak \\
Pangunan ukur & Aliran & Tidak \\
Bangunan ukur & Atas & \\
Cipoletti & Atas & Tidak \\
$\begin{array}{l}\text { Bangunan ukur } \\
\text { Romijn }\end{array}$ & Aliran \\
Atas & Ya \\
$\begin{array}{l}\text { Bangunan ukur } \\
\text { Crump-de }\end{array}$ & Aliran & Ya \\
Gruyter & Bawah & \\
Bangunan sadap & Aliran & Ya \\
\hline
\end{tabular}




\begin{tabular}{|l|c|c|}
\hline Pipa sederhana & Aliran & Ya \\
Constant-Head & Bawah & \\
Orifice $(\mathrm{CHO})$ & Aliran & Tidak \\
Cut Throat Flume & Atas & \\
\hline
\end{tabular}

Sumber : Standar Perencanan Irigasi KP.01,2010

Untuk menyederhanakan operasi dan pemeliharaan, bangunan ukur yang dipakai di sebuah jaringan irigasi hendaknya tidak terlalu banyak, dan diharapkan pula pemakaian alat ukur tersebut bisa benar-benar mengatasi permasalahan yang dihadapi para petani. KP-04 Bangunan memberikan uraian terinci mengenai peralatan ukur dan penggunaannya.

Peralatan berikut dianjurkan pemakaiannya :

a. Di Hulu Saluran Primer

Untuk aliran besar alat ukur ambang lebar dipakai untuk pengukuran dan pintu sorong atau radial untuk pengatur.

b. Di Bangunan Bagi Bangunan Sadap Sekunder

Pintu Romijn dan pintu Crump-de Gruyter dipakai untuk mengukur dan mengatur aliran. Bila debit terlalu besar, maka alat ukur ambang lebar dengan pintu sorong atau radial bisa dipakai seperti untuk saluran primer.

c. Bangunan Sadap Tersier

Dalam mengatur dan mengukur aliran dipakai alat ukur Romijn atau jika fluktuasi di saluran besar dapat dipakai alat ukur Crump-de Gruyter. Di petak-petak tersier kecil di sepanjang saluran primer dengan tinggi muka air yang bervariasi dapat dipertimbangkan untuk memakai bangunan sadap pipa sederhana, di lokasi yang petani tidak bisa menerima bentuk ambang sebaiknya dipasang alat ukur parshall atau cut throat flume. Alat ukur parshall memerlukan ruangan yang panjang, presisi yang tinggi dan 
sulit pembacaannya, alat ukur cut throat flume lebih pendek dan mudah pembacaannya.

\section{Bangunan Pengatur Muka Air}

Bangunan-bangunan pengatur muka air mengatur / mengontrol muka air di jaringan irigasi utama sampai batasbatas yang diperlukan untuk dapat memberikan debit yang konstan kepada bangunan sadap tersier. Bangunan pengatur mempunyai potongan pengontrol aliran yang dapat distel atau tetap. Untuk bangunan-bangunan pengatur yang dapat disetel dianjurkan untuk menggunakan pintu (sorong) radial atau lainnya. Bangunanbangunan pengatur diperlukan di tempat-tempat di mana tinggi muka air di saluran dipengaruhi oleh bangunan terjun atau got miring (chute). Untuk mencegah meninggi atau menurunnya muka air di saluran dipakai mercu tetap atau celah kontrol trapesium (trapezoidal notch).

\section{Bangunan Pembawa}

Bangunan-bangunan pembawa membawa air dari ruas hulu ke ruas hilir saluran. Aliran yang melalui bangunan ini bisa superkritis atau subkritis.

\section{Bangunan Pembawa Dengan Aliran Superkritis}

Bangunan pembawa dengan aliran tempat di mana lereng medannya maksimum saluran. Superkritis diperlukan di tempat lebih curam daripada kemiringan maksimal saluran. (Jika di tempat dimana kemiringan medannya lebih curam daripada kemiringan dasar saluran, maka bisa terjadi aliran superkritis yang akan dapat merusak saluran. Untuk itu diperlukan bangunan peredam).

a. Bangunan Terjun

Dengan bangunan terjun, menurunnya muka air (dan tinggi energi) dipusatkan di satu tempat Bangunan terjun bisa memiliki terjun tegak atau terjun miring. Jika perbedaan tinggi energi mencapai beberapa meter, maka konstruksi got miring perlu dipertimbangkan.

b. Got miring 
Daerah got miring dibuat apabila trase saluran rnelewati ruas medan dengan kemiringan yang tajam dengan jumlah perbedaan tinggi energi yang besar. Got miring berupa potongan saluran yang diberi pasangan (lining) dengan aliran superkritis, dan umurnnya mengikuti kemiringan medan alamiah.

\section{Bangunan Pembawa Dengan Aliran Subkritis (bangunan silang)}

a. Gorong-gorong

Gorong-gorong dipasang di tempat-tempat di mana saluran lewat di bawah bangunan (jalan, rel kereta api) atau apabila pembuang lewat di bawah saluran. Aliran di dalam gorong-gorong umumnya aliran bebas.

b. Talang

Talang dipakai untuk mengalirkan air irigasi lewat di atas saluran lainnya, saluran pembuang alamiah atau cekungan dan lembah-lembah. Aliran di dalam talang adalah aliran bebas.

c. Sipon

Sipon dipakai untuk mengalirkan air irigasi dengan menggunakan gravitasi di bawah saluran pembuang, cekungan, anak sungai atau sungai. Sipon juga dipakai untuk melewatkan air di bawah jalan, jalan kereta api, atau bangunan-bangunan yang lain. Sipon merupakan saluran tertutup yang direncanakan untuk mengalirkan air secara penuh dan sangat dipengaruhi oleh tinggi tekan.

d. Jembatan sipon

Jembatan sipon adalah saluran tertutup yang bekerja atas dasar tinggi tekan dan dipakai untuk mengurangi ketinggian bangunan pendukung di atas lembah yang dalam.

e. Flum (Flume)

Ada beberapa tipe flum yang dipakai untuk mengalirkan air irigasi melalui situasi-situasi medan tertentu, misalnya: 
1) flum tumpu (bench flume), untuk mengalirkan air di sepanjang lereng bukit yang curam

2) flum elevasi (elevated flume), untuk menyeberangkan air irigasi lewat di atas saluran pembuang atau jalan air lainnya

3) flum, dipakai apabila batas pembebasan tanah (right of way) terbatas atau jika bahan tanah tidak cocok untuk membuat potongan melintang saluran trapesium biasa.

Flum mempunyai potongan melintang berbentuk segi empat atau setengah bulat. Aliran dalam flum adalah aliran bebas.

f. Saluran tertutup

Saluran tertutup dibuat apabila trase saluran terbuka melewati suatu daerah di mana potongan melintang harus dibuat pada galian yang dalam dengan lereng-Iereng tinggi yang tidak stabil. Saluran tertutup juga dibangun di daerah-daerah permukiman dan di daerah-daerah pinggiran sungai yang terkena luapan banjir. Bentuk potongan melintang saluran tertutup atau saluran gali dan timbun adalah segi empat atau bulat. Biasanya aliran di dalam saluran tertutup adalah aliran bebas.

g. Terowongan

Terowongan dibangun apabila keadaan ekonomi/anggaran memungkinkan untuk saluran tertutup guna mengalirkan air melewati bukit-bukit dan medan yang tinggi. Biasanya aliran di dalam terowongan adalah aliran bebas.

\section{F. Bangunan Lindung}

Bangunan lindung diperlukan untuk melindungi saluran baik dari dalam maupun dari luar. Dari luar bangunan itu memberikan perlindungan terhadap limpasan air buangan yang berlebihan dan dari dalam terhadap aliran saluran yang 
berlebihan akibat kesalahan eksploitasi atau akibat masuknya air dan luar saluran.

1. Bangunan Pembuang Silang

Gorong-gorong adalah bangunan pembuang silang yang paling umum digunakan sebagai lindungan-luar; lihat juga pasal mengenai bangunan pembawa.

Sipon dipakai jika saluran irigasi kecil melintas saluran pembuang yang besar. Dalam hal ini, biasanya lebih aman dan ekonomis untuk membawa air irigasi dengan sipon lewat di bawah saluran pembuang tersebut.

Overchute akan direncana jika elevasi dasar saluran pembuang di sebelah hulu saluran irigasi lebih besar daripada permukaan air normal di saluran.

2. Pelimpah (Spillway)

Ada tiga tipe lindungan-dalam yang umum dipakai, yaitu saluran pelimpah, sipon pelimpah dan pintu pelimpah otomatis. Pengatur pelimpah diperlukan tepat di hulu bangunan bagi, di ujung hilir saluran primer atau sekunder dan di tempat-tempat lain yang dianggap perlu demi keamanan jaringan. Bangunan pelimpah bekerja otomatis dengan naiknya muka air.

3. Bangunan Penggelontor Sedimen (Sediment Excluder)

Bangunan ini dimaksudkan untuk mengeluarkan endapan sedimen sepanjang saluran primer dan sekunder pada lokasi persilangan dengan sungai. Pada ruas saluran ini sedimen diijinkan mengendap dan dikuras melewati pintu secara periodik.

4. Bangunan Penguras (Wasteway)

Bangunan penguras, biasanya dengan pintu yang dioperasikan dengan tangan, dipakai untuk mengosongkan seluruh ruas saluran bila diperlukan. Untuk mengurangi tingginya biaya, bangunan ini dapat digabung dengan bangunan pelimpah.

5. Saluran Pembuang Samping

Aliran buangan biasanya ditampung di saluran pembuang terbuka yang mengalir pararel di sebelah atas 
saluran irigasi. Saluran-saluran ini membawa air ke bangunan pembuang silang atau, jika debit relatif kecil dibanding aliran air irigasi, ke dalam saluran irigasi itu melalui lubang pembuang.

6. Saluran Gendong

Saluran gendong adalah saluran drainase yang sejajar dengan saluran irigasi, berfungsi mencegah aliran permukaan (run off) dari luar areal irigasi yang masuk ke dalam saluran irigasi. Air yang masuk saluran gendong dialirkan keluar ke saluran alam atau drainase yang terdekat.

\section{G. Jalan dan Jembatan}

Jalan dan jembatan diperlukan untuk pemerikan dan pengwasan pemeliharaan jaringan irigasi dan pembuang oleh Dinas Pengairan. Masyarakat boleh menggunakan jalan-jalan inspeksi ini untuk keperluan-keperluan tertentu saja. Apabila saluran dibangun sejajar dengan jalan umum didekatnya, maka tidak diperlukan jalan inspeksi di sepanjang ruas saluran tersebut. Biasanya jalan inspeksi terletak di sepanjang sisi saluran irigasi. Jembatan dibangun untuk saling menghubungkan jalan-jalan inspeksi di seberang saluran irigasi/pembuang atau untuk menghubungkan jalan inspeksi dengan jalan umum. Perlu dilengkapi jalan petani ditingkat jaringan tersier dan kuarter sepanjang itu memang diperlukan oleh petani setempat dan dengan persetujuan petani setempat pula, karena banyak ditemukan di lapangan jalan petani yang rusak atau tidak ada sama sekali sehingga akses petani dari dan ke sawah menjadi terhambat, terutama untuk petak sawah yang paling ujung.

\section{H. Bangunan Pelengkap}

Bangunan pelengkap berupa tanggul-tanggul diperlukan untuk melindungi daerah irigasi terhadap banjir yang berasal dari sungai atau saluran pembuang yang besar. Pada umumnya tanggul diperlukan di sepanjang sungai di sebelah hulu bendung atau di sepanjang saluran primer. Fasilitas- 
fasilitas operasional diperlukan untuk operasi jaringan irigasi secara efektif dan aman. Fasilitas-fasilitas tersebut antara lain meliputi antara lain: kantor-kantor di lapangan, bengkel, perumahan untuk staf irigasi, jaringan komunikasi, patok hektometer, papan eksploitasi, papan duga, dan sebagainya. Bangunan-bangunan pelengkap yang dibuat di dan sepanjang saluran meliputi:

1. Pagar, rel pengaman dan sebagainya, guna memberikan pengaman sewaktu terjadi keadaan-keadaan gawat;

2. Tempat-tempat cuci, tempat mandi ternak dan sebagainya, untuk memberikan sarana untuk mencapai air di saluran tanpa merusak lereng;

3. Kisi-kisi penyaring untuk mencegah tersumbatnya bangunan (sipon dan gorong-gorong panjang) oleh bendabenda yang hanyut;

4. Jembatan-jembatan untuk keperluan penyeberangan bagi penduduk.

5. Sanggar tani sebagai sarana untuk interaksi antar petani, dan antara petani dan petugas irigasi dalam rangka memudahkan penyelesaian permasalahan yang terjadi di lapangan. Pembangunannya disesuaikan dengan kebutuhan dan kondisi petani setempat serta letaknya di setiap bangunan sadap/offtake.

\section{Standar Tata Nama}

Standar tata nama yang diberikan untuk saluran-saluran irigasi dan pembuang, bangunan-bangunan dan daerah irigasi harus jelas dan logis. Nama yang diberikan harus pendek dan tidak mempunyai tafsiran ganda (ambigu). Nama-nama harus dipilih dan dibuat sedemikian sehingga jika dibuat bangunan baru kita tidak perlu mengubah semua nama yang sudah ada.

\section{J. Daerah Irigasi}

Daerah irigasi diberi nama sesuai dengan nama daerah setempat, atau desa penting di daerah itu, yang biasanya terletak dekat dengan jaringan bangunan utama atau sungai yang airnya diambil untuk keperluan irigasi. Contohnya adalah 
Daerah Irigasi Kelingi Tugumulyo, Daerah Irigasi Jatiluhur . Cikoncang Apabila ada dua pengambilan atau lebih, maka daerah irigasi tersebut sebaiknya diberi nama sesuai dengan desa-desa terkenal di daerah-daerah layanan setempat. Untuk pemberian nama-nama bangunan utama berlaku peraturan yang sama seperti untuk daerah irigasi, misalnya bendung Watervang melayani D.I Kelingi Tugumulyo..

Sebagai contoh, lihat Gambar 1.5. Bendung Barang merupakan salah satu dari bangunan-bangunan utama di sungai Dolok. Bangunan-bangunan tersebut melayani daerah Makawa dan Lamogo, keduanya diberi nama sesuai dengan nama-nama desa utama di daerah itu.

\section{K. Jaringan Irigasi}

\section{Jaringan Irigasi Primer}

Jaringan irigasi primer atau Saluran irigasi primer sebaiknya diberi nama sesuai dengan daerah irigasi yang dilayani, contoh: saluran primer Makawa. Saluran sekunder sering diberi nama sesuai dengan nama desa yang terletak di petak sekunder. Petak sekunder akan diberi nama sesuai dengan nama saluran sekundernya. Sebagai contoh saluran sekunder Sambak mengambil nama desa Sambak yang terletak di petak sekunder Sambak.

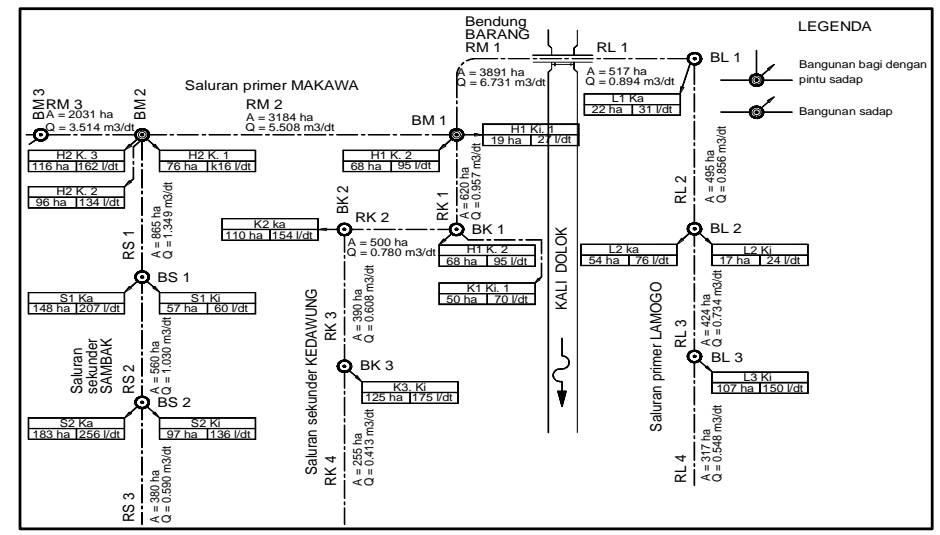

Gambar.1.6. Standar Sistem Tata Nama Untuk Skema Irigasi

Sumber: Standar Perencanan Irigasi KP.01,2010 


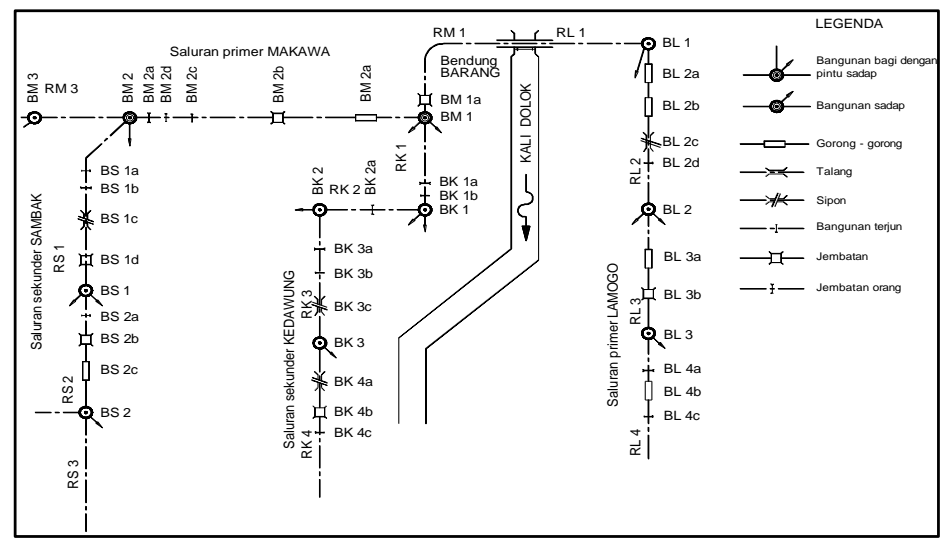

\section{Gambar 1.7. Standar Sistem Tata Nama untuk Bangunan- Bangunan Irigasi}

Sumber : Standar Perencanan Irigasi KP.01,2010

\section{Jaringan Irigasi Tersier}

Petak tersier diberi nama seperti bangunan sadap tersier dari jaringan utama. Misalnya petak tersier S1 ki mendapat air dari pintu kiri bangunan bagi BS 1 yang terletak di saluran Sambak.

a. Ruas-ruas saluran tersier diberi nama sesuai dengan nama boks yang terletak di antara kedua boks. misalnya (T1 - T2), (T3 - K1), (Gambar 1.8).

b. Boks Tersier diberi kode $\mathrm{T}$, diikuti dengan nomor urut menurut arah jarum jam, mulai dari boks pertama di hilir bangunan sadap tersier: T1, T2 dan sebagainya

c. Petak kuarter diberi nama sesuai dengan petak rotasi, diikuti dengan nomor urut menurut arah jarum jam. Petak rotasi diberi kode A, B, C dan seterusnya menurut arah jarum jam.

d. Boks kuarter diberi kode $\mathrm{K}$, diikuti dengan nomor urut menurut arah jarum jam, mulai dari boks kuarter pertama di hilir boks tersier dengan nomor urut tertinggi: K1, K2 dan seterusnya. 


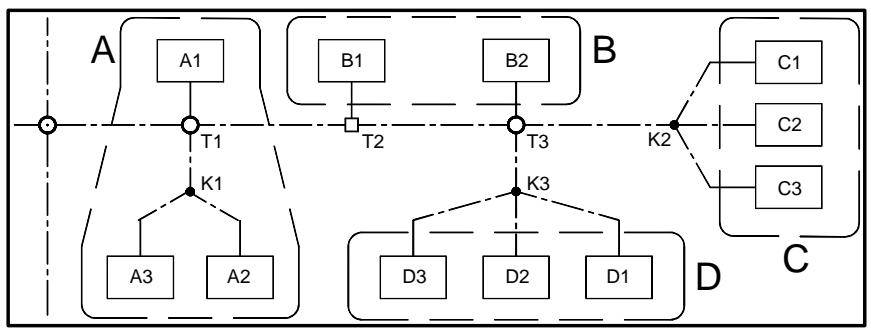

\section{Gambar 1.8. Sistem tata nama petak rotasi dan kuarter} Sumber: Standar Perencanan Irigasi KP.01,2010

e. Saluran irigasi kuarter diberi nama sesuai dengan petak kuarter yang dilayani tetapi dengan huruf kecil, misalnya a1,a2 dan seterusnya.

f. Saluran pembuang kuarter diberi nama sesuai dengan petak kuarter yang dibuang airnya, menggunakan huruf kecil diawali dengan $\mathrm{dk}$, misalnya dka1, dka2 dan seterusnya.

g. Saluran pembuang tersier, diberi kode dt1, dt2 juga menurut arah jarum jam.

\section{Jaringan Pembuang}

Setiap pembangunan atau pembuatan jaringan irigasi dilengkapi dengan pembangunan jaringan drainase yang merupakan satu kesatuan dengan jaringan irigasi yang bersangkutan. Biasanya saluran pembuang primer berupa sungai-sungai alamiah, yang kesemuanya akan diberi nama. Apabila ada saluran-saluran pembuang primer baru yang akan dibuat, maka saluran-saluran itu harus diberi nama tersendiri. Jika saluran pembuang dibagi menjadi ruas-ruas, maka masing-masing ruas akan diberi nama, mulai dari ujung hilir. Pembuang sekunder pada umumnya berupa sungai atau anak sungai yang lebih kecil. Beberapa di antaranya sudah mempunyai nama yang tetap bisa dipakai, jika tidak sungai/anak sungai tersebut akan ditunjukkan dengan sebuah huruf bersama-sama dengan nomor seri Nama-nama ini akan diawali dengan huruf $d(d=$ drainase $)$. 
Pembuang tersier adalah pembuang kategori terkecil dan akan dibagi-bagi menjadi ruas-ruas dengan debit seragam, masing-masing diberi nomor. Masing-masing petak tersier akan mempunyai nomor seri sendiri-sendiri. Gambar 1.7. merupakan contoh sistem tata nama untuk saluran pembuang.

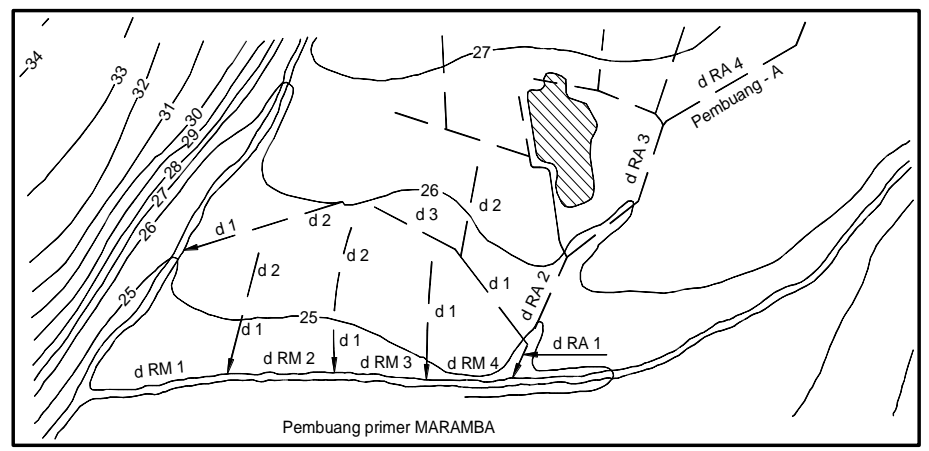

\section{Gambar 1.9. Sistem Tata Nama Jaringan Pembuang}

Sumber: Standar Perencanan Irigasi KP.01,2010

\section{Tata Warna Peta}

Tata Warna Peta dan Warna-warna standar akan digunakan untuk menunjukkan berbagai tampakan irigasi pada peta. Menurut Standar Perencanan Irigasi KP.01,2010,Warna-warna yang dipakai adalah :

1. Biru untuk jaringan irigasi, garis penuh untuk jaringan pembawa yang ada dan garis putus-putus untuk jaringan yang sedang direncanakan

2. Merah untuk sungai dan jaringan pembuang garis penuh untuk jaringan yang sudah ada dan garis putus-putus (----- ---- - ----) untuk jaringan yang sedang direncanakan;

3. Coklat untuk jaringan jalan;

4. Kuning untuk daerah yang tidak diairi (dataran tinggi, rawa-rawa);

5. Hijau untuk perbatasan kabupaten, kecamatan desa dan kampung;

6. Merah untuk tata nama bangunan; 
7. Hitam untuk jalan kereta api;

Warna bayangan akan dipakai untuk batas-batas petak sekunder, batas-batas petak tersier akan diarsir dengan warna yang lebih muda dari warna yang sama (untuk petak sekunder) semua petak tersier yang diberi air langsung dari saluran primer akan mempunyai warna yang sama. Akan di lebih jelas jelaskan pada bab 10.

\section{Sumber Air Irigasi}

Ada tiga Sumber air irigasi, yaitu :

1. Mata Air

Mata Air yaitu air yang terdapat di dalam tanah, seperti sumur, air artesis, dan air tanah. Air tersebut banyak mengandung zat terlarut sehingga mineral bahan makan tanaman sangat kurang dan pada umumnya konstan.

2. Air Sungai

Air Sungai, yaitu air yang terdapat di atas permukaan tanah. Air tersebut banyak mengandung lumpur yang mengandung mineral sebagai bahan makan makanan, sehingga sangat baik untuk pemupukan dan juga suhunya lebih rendah daripada suhu atmosfer. Air sungai ini berasal dari dua macam sungai, yaitu sungai kecil yang debit airnya berubah-ubah dan sungai besar.

3. Air Waduk

Air Wadukadalah air yang terdapat di permukaan tanah, seperti pada sungai. Tetapi air waduk sedikit mengandung lumpur, sedangkan zat terlarutnya sama banyaknya dengan air sungai. Air waduk di sini dapat dibedakan menjadi dua macam, yaitu waduk alami dan waduk buatan manusia. Air waduk juga dibedakan menjadi dua macam menurut keuntungan yang diperoleh, yaitu waduk multi purpose atau waduk dengan keuntungan yang diperoleh lebih dari satu. Misalnya air waduk selain untuk pertanian juga untuk perikanan, penanggulangan banjir, pembangkit listrik dan pariwisata. Tetapi ada juga waduk yang hanya digunakan untuk pertanian saja. 
Sebagian besar sumber air untuk irigasi adalah air permukaan yang berasal dari air hujan dan pencairan salju. Air ini secara alami mengalir di sungai sungai, yang membawanya ke laut. Jika dimanfaatkan untuk irigasi, sungai dibendung dan dialirkan melalui saluran-saluran buatan ke daerah pertanian, atau air terlebih dahulu ditampung di dalam waduk yang selanjutnya dialirkan secara teratur melalui jaringan irigasi ke daerah pertanian.

Adapun faktor-faktor yang menentukan pemilihan metode pemberian air irigasi antara lain adalah :

a. Distribusi musiman hujan,

b. Kemiringan lereng,

c. Bentuk permukaan lahan,

d. Suplai air,

e. Rotasi tanaman dan,

f. Permeabilitas tanah lapisan bawah.

\section{N. Metoda pendistribusian air irigasi}

Menurut Sudjarwadi, 1990, Metoda pendistribusian air irigasi dapat dibagi menjadi sebagai berikut :

\section{Irigasi Permukaan (Surface Irrigation)}

Irigasi permukaan dapat dikelompokkan menjadi dua, yaitu :

a. Peluapan dan penggenangan bebas (tanpa kendali),

b. Peluapan penggenangan secara terkendali.

Sistem irigasi permukaan yang paling sederhana adalah peluapan bebas dan penggenangan. Dalam hal ini air diberikan pada areal irigasi dengan jalan peluapan untuk menggenangi kiri atau kanan sungai yang mempunyai permukaan datar.

\section{Irigasi Lapisan Bawah (Sub Surface Irrigation)}

Sistem irigasi bawah permukaan dapat dilakukan dengan meresapkan air ke dalam tanah di bawah zona perakaran melalui sistem saluran terbuka ataupun dengan menggunakan pipa porus. Lengas tanah digerakkan oleh gaya kapiler menuju zona perakaran dan selanjutnya dimanfaatkan oleh tanaman 


\section{Sprinkler (Sprinkle Irrigation)}

Prinsip yang digunakan sistem ini adalah memberi tekanan pada air dalam pipa dan memancarkan ke udara sehingga menyerupai hujan selanjutnya jatuh pada permukaan tanah. Cara pemancaran dapat dilakukan dengan berbagai variasi, antara lain dengan menggunakan

pipa porus ataupun menggunakan alat pancar yang bisa berputar. Untuk dapat memberikan siraman yang merata sering digunakan alat pancar yang diletakkan di atas kereta dan dapat berpindah-pindah

\section{Irigasi Tetes (trickle irrigation atau drip irrigation)}

Sistem irigasi tetes sering disebut dengan trickle irrigation atau kadang kadang drip irrigation. Sistem yang digunakan adalah dengan memakai pipa-pipa dan pada tempat-tempat tertentu diberi lubang untuk jalan keluarnya air menetes ke tanah. Perbedaan dengan sistem pancaran adalah besarnya tekanan pada pipa yang tidak begitu besar

Sesui dengan perkembangannya, irigasi dibagi menjadi 3 tipe, yaitu :

a. Irigasi Sistem Gravitasi

Irigasi gravitasi merupakan sistem irigasi yang telah lama. dikenal dan diterapkan dalam kegiatan usashatani. Dalam sistem irigasi ini, sumber air diambil dari air yang ada di permukaan burni yaitu dari sungai, waduk dah danau di dataran tinggi. Pengaturan dan pembagian air irigasi menuju ke petak-petak yang membutuhkan, dilakukan secara gravitatif.

b. Irigasi Sistem Pompa

Sistem irigasi dengan pompa bisa dipertimbangkan, apabila pengambilan secara gravitatif ternyata tidak layak dari segi ekonomi maupun teknik. Cara ini membutuhkan modal kecil, namun memerlukan biaya ekspoitasi yang besar. Sumber air yang dapat dipompa untuk keperluan irigasi dapat diambil dari sungai

c. Irigasi Pasang-surut 
Sistem irigasi pasang-surut adalah suatu tipe irigasi yang memanfaatkan pengempangan air sungai akibat peristiwa pasang-surut air laut. Areal yang direncanakan untuk tipe irigasi ini adalah areal yang mendapat pengaruh langsung dari peristiwa pasangsurut air laut. Untuk daerah Kalimantan misalnya, daerah ini bisa mencapai panjang $30-50 \mathrm{~km}$ memanjang pantai dan 10 - $15 \mathrm{~km}$ masuk ke darat. Air genangan yang berupa air tawar dari sungai akan menekan dan mencuci kandungan tanah sulfat masam dan akan dibuang pada saat air laut surut. 


\section{DAFTAR PUSTAKA}

Christa Emanuel Sembiring, 2016, Analisi Debit Air Irigasi (Suplai Dan Kebutuhan ) Di Sekampung Sistem, Tesisi, Program Pascasarjana Magister Teknik Sipil Fakultas Teknik Universitas Lampung 2016

Okma Yendri, Alaik Yahya Muafi, Nurnilam Oemiati,2019, Pengaruh fluktuasi muka air terhadap debit aliran pada Sungai ketupak pada saat musim penghujan. CANTILEVER, Volume: 8 | Nomor: 1 | April 2019 | ISSN: 1907-4247 (Print) | ISSN: 2477-4863 (Online) | Website: http://cantilever.unsri.ac.id

Okma Yendri, Dinar DA Putranto, Sarino ,2919 Analisis Besaran Komponen Imbangan Air pada Lahan Irigasi Kelingi Tugumulyo Kabupaten Musi Rawas Provinsi Sumatera Selatan, Civronlit, Volume 4 No2 e-ISSN ; 2548-6209 p-ISSN ; 2089-2098,

http://jt.unbari.ac.id/index.php/CIVRONLIT/index

RN. Reddy 2010.Irrigation Engineering, Chawla Offset Printers, New Delhi - 110052

Deapartemen Pekerjaan Umum, 2010. Standar Perencanan Irigasi KP.01,2010

PP.No.20 tahun 2006, 2006, Peraturan Pemerintah Republik Indonesia Nomor 20 Tahun 2006 Tentang Irigasi

Sudjarwadi, 1990, TeoridanPraktek Irigasi.PusatAntar Universitas Ilmu Teknik,Universitas Gajah Mada. Yogyakarta. 